\title{
Factors determining parasite abundance in European perch, Perca fluviatilis, European whitefish, Coregonus lavaretus, and Arctic charr, Salvelinus alpinus, in an oligotrophic lake, southern Norway.
}

\author{
Tom Robin Olk', Ann-Cecilie Henriksen², Solveig Irene Dolven', Mathias Leithe Haukø', Espen Lydersen', Tor Atle Mo ${ }^{3}$
}

Olk TR, Henriksen A-C, Dolven SI, Leithe Haukø M, Lydersen E and Mo TA. 2020. Factors determining parasite abundance in European perch, Perca fluviatilis, European whitefish, Coregonus lavaretus, and Arctic charr, Salvelinus alpinus, in an oligotrophic lake, southern Norway. Fauna norvegica 40: 109-129.

\begin{abstract}
Temporal and spatial variations in macroparasite status were investigated in European perch, Perca fluviatilis, European whitefish, Coregonus lavaretus, and Arctic charr, Salvelinus alpinus in Lake Norsjø (Southern Norway), based on gillnet fishing in three locations in the spring, summer, and fall 2018. In addition, length, weight, age, sex, $\delta^{13} \mathrm{C}$, and $\delta^{15} \mathrm{~N}$ were determined. Parasite abundance was modelled using negative binomial generalized linear models in relation to fish metrics, season, and sampling location. The most prevalent parasite species were determined by the diet and habitat of the host. European perch was mainly infected by acanthocephalans, European whitefish mainly infected by acanthocephalans and cestodes, and Arctic charr mainly infected by cestodes. The most prevalent parasites in European perch are transmitted by benthic animals. Parasites in European whitefish are transmitted by both benthic animals and copepods, while the most prevalent parasites in Arctic charr are copepod transmitted. This corresponds well with the $\delta^{13} \mathrm{C}$ signatures in the three species, indicating that European perch primarily fed in the littoral zone $\left(\delta^{13} \mathrm{C}:-24.9 \pm 2.5 \%\right)$, Arctic charr in the pelagic and profundal zone $\left(\delta^{13} \mathrm{C}:-29.4\right.$ $\pm 1.1 \%$ ), while European whitefish both fed in the littoral and pelagic zone $\left(\delta^{13} \mathrm{C}:-28.3 \pm 2.3 \%\right.$ of Lake Norsjø. Individual abundances of parasites depended on host age, length, sex, $\delta^{15} \mathrm{~N}$, and season. Positive correlations between parasite abundance and host age, length, or trophic level measured as $\delta^{15} \mathrm{~N}$ were most common, and occurred in all three host species. Many parasites accumulate with age, and larger hosts provide more diverse habitats for parasites.
\end{abstract}

doi: 10.5324/fn.v40i0.3444. Received: 2020-02-27. Accepted: 2020-07-01. Published online: 2020-08-18. ISSN: $1891-5396$ (electronic).

Keywords: freshwater fish, macroparasites, parasite abundance, Norway

1. Department of Natural Sciences and Environmental Health, University of Southeast Norway, Gullbringvegen 36, NO-3800, Bø, Midt-Telemark, Norway

2. Akvaplan-niva, Markedsgata 3, NO-9504, Alta, Norway

3. Norsk Institutt for Naturforskning - NINA, Gaustadalléen 21, NO-0349, Oslo, Norway

Corresponding author: Tom Robin Olk

E-mail:tom.robin.olk@usn.no

\section{INTRODUCTION}

Species composition of parasite communities and parasite abundance in freshwater fish are determined by various biotic and abiotic factors. Abundance, which is the number of parasites in an individual host, is subject to higher fluctuations due to stochastic factors than species composition (Timi et al. 2010; Timi \& Lanfranchi 2013; Locke et al. 2013). One of the most important determinants of parasite community structure and abundance is host ecology (Kennedy 1978; Bush et al. 1990; Poulin 1995; Locke et al. 2014), and parasite communities are highly dependent on habitat and diet of the host (Knudsen et al. 2008). Parasite abundance can be linked to information on niche use, for instance by analysis of stable carbon isotope signatures $\left(\delta^{13} \mathrm{C}\right)$, stomach samples or head shape (Knudsen et al. 2014). Parasite abundance is also influenced by the age of the host (Khan 2012), as longevity provides a more stable habitat for parasites and allows for accumulation of parasites over time (Bell \& Burt 1991). Increasing host body size also increases parasite abundance (e. g. Poulin 2000, 2004; Valtonen et al. 2010; Timi \& Lanfranchi 2013; Anegg et al. 2014). Larger hosts provide a greater diversity of niches and more space for parasites (Poulin 1995; Poulin \& Leung 2011), as well as they consume more food, increasing the chance of contracting a parasite infection (Poulin 1997). Larger fish also feed on larger prey, with higher diversity of potential parasites (Timi et al. 2011). However, not all studies confirm higher parasite abundance for larger hosts (Balling \& Pfeiffer 1997; Poulin 2007; Luque \& Poulin 2008). Another factor influencing parasite community structure and abundance is the trophic position of the host (Luque \& Poulin 2008; Timi et al. 2011; Alarcos \& Timi 2012), with higher diversities of parasites observed at higher trophic levels (Chen et al. 2008; Knudsen et al. 2008). 
Especially piscivorous fish have higher abundances of parasites (Valtonen et al. 2010), as parasites accumulate in predators through the food chain (Valtonen \& Julkunen 1995), and some parasites are able to reestablish in predatory fish (Bérubé \& Curtis 1984; Sandlund et al. 1992). However, not all studies reveal a correlation between parasite abundances and trophic position (Knudsen et al. 2014). In some studies, parasite abundance is also shown to vary by sex (Balling \& Pfeiffer 1997). In addition, some parasite-host systems exhibit seasonal fluctuations in parasite abundance (Andersen 1978; Scott \& Smith 1994).

Studies on parasites of freshwater fish in southern Norway have mainly been conducted during the 1950s to 1970s, and focused on the parasites development and lifespan (Lien 1970), single parasitehost interactions (Halvorsen 1970), the occurrence of parasites (Vik 1959, 1963; Borgström \& Lien 1973), and the occurrence of parasites combined with seasonal variations in abundance (Halvorsen 1968, 1972; Skorping 1977, 1981; Andersen 1978). However, there is one recent publication investigating parasite community structure and abundance related to trophic niche and habitat in southern Norway (Paterson et al. 2019). In this study, we have explored factors determining the abundance of numerous macroparasites in three species of freshwater fish, Arctic charr, Salvelinus alpinus (Linnaeus, 1758), hereafter: charr, European perch, Perca fluviatilis Linnaeus, 1758, hereafter: perch and European whitefish, Coregonus lavaretus (Linnaeus, 1758), hereafter: whitefish, in a large, oligotrophic lake in southern Norway.

\section{MATERIAL AND METHODS}

\section{Study Site}

Lake Norsjø is a large $\left(55.48 \mathrm{~km}^{2}\right)$ lake in Vestfold and Telemark county, South-Eastern Norway. The lake is $30 \mathrm{~km}$ long and has an average width of $3 \mathrm{~km}$ and a lake volume of $5.1 \mathrm{~km}^{3}$. Its maximum depth is $171 \mathrm{~m}$, with a mean depth of $87 \mathrm{~m}$. Lake Norsjø is located at 15 m. a. s. 1. as part of the Telemark watercourse (Vann-Nett 2019). Three main rivers enter Lake Norsjø, which are all draining mountain areas north west in the county. In south, Lake Norsjø is dammed at Skotfoss, the outlet of the lake, where the River Skienselva starts. The lake regulation is minor, only $<1 \mathrm{~m}$ (Vann-Nett 2019). Lake Norsjø is classified as an oligotrophic Norwegian lake (Lyche Solheim \& Skotte 2016). Human activities with moderate impacts on the lake are agriculture, industry, and recreational activities (Vann-Nett 2019). According to Jensen (1954), Lake Norsjø houses charr, brown trout, Salmo trutta Linnaeus, 1758, Northern pike, Esox lucius Linnaeus, 1758, perch, whitefish, Atlantic salmon, Salmo salar Linnaeus, 1758, European smelt, Osmerus eperlanus (Linnaeus, 1758), European eel, Anguilla Anguilla (Linnaeus, 1758), Crucian carp, Carassius carassius (Linnaeus, 1758), river lamprey, Lampetra fluviatilis (Linnaeus, 1758), Eurasian minnow, Phoxinus phoxinus (Linnaeus, 1758), tench, Tinca tinca (Linnaeus, 1758), and three-spined sticklebacks, Gasterosteus aculeatus (Linnaeus, 1758).

Fish were sampled in three locations north, in the middle, and south of Lake Norsjø (Figure 1). The northern sampling site is located in Årnes Bay close to the inlets of River Bøelva and River Sauarelva. Ånes Bay is mostly shallow ( $<10 \mathrm{~m}$ depth) with a maximum depth about $30 \mathrm{~m}$. The area is surrounded by wetland vegetation. The sampling site in the middle of the lake is located by the inlet of River Eidselva close to the town Ulefoss. This area is deeper with a maximum depth up to $60 \mathrm{~m}$. The southern sampling site is located

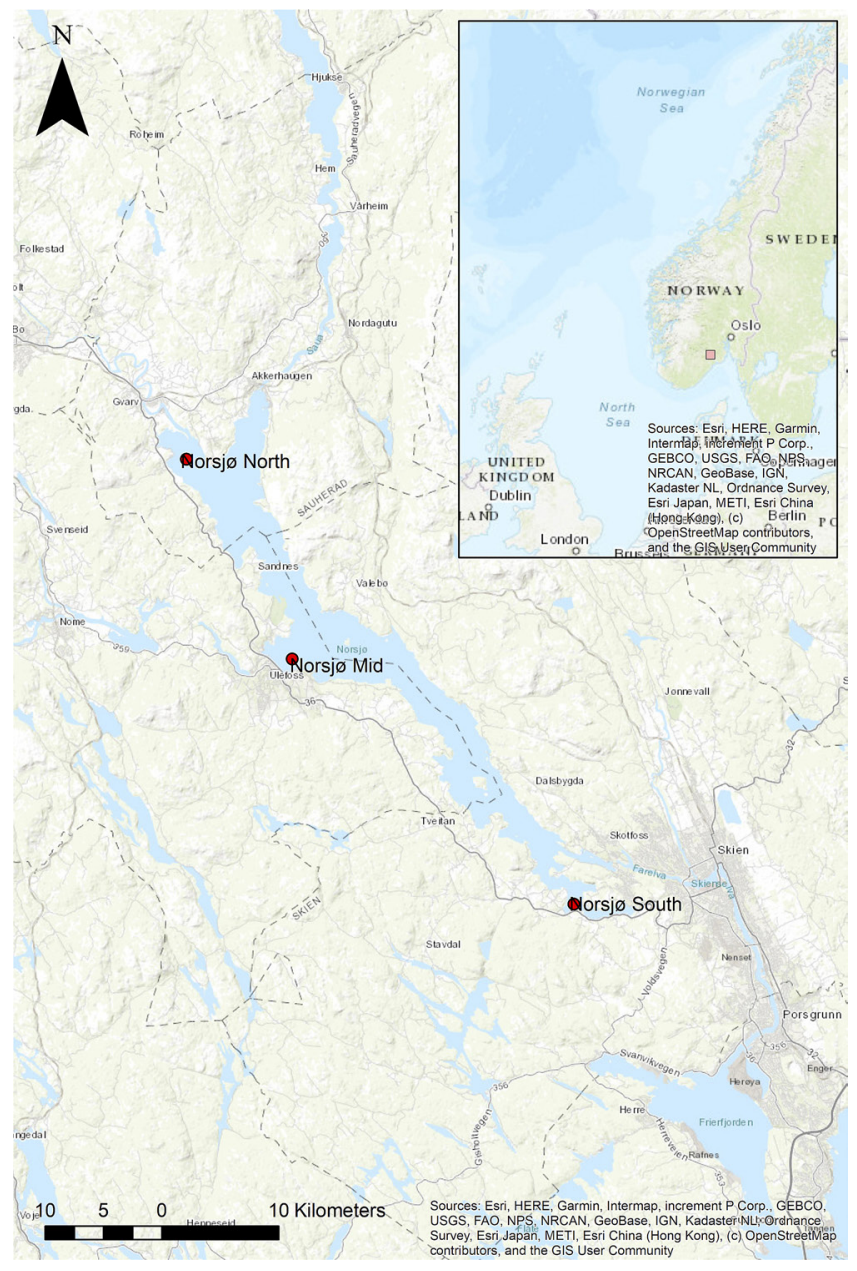

Figure I. The study area Lake Norsjø with three study locations, Norsjø North $\left(59.371806^{\circ} \mathrm{N} 9.191388^{\circ} \mathrm{E}\right)$, Norsjø $\operatorname{Mid}\left(59.288811^{\circ} \mathrm{N} 9.280637^{\circ} \mathrm{E}\right)$, and Norsjø South $\left(59.214154^{\circ} \mathrm{N} 9.472426^{\circ} \mathrm{E}\right)$. Source: ArcGIS (ESRI 2012).

where the lake divides into two areas. One of the areas is the relatively shallow $(<30 \mathrm{~m}$ depth) outlet area at Skotfoss. The other area is Fjærekilen Bay, which is deeper (>60 m depth). The sampling site is located in Fjærekilen Bay.

\section{Sampling}

Fish were sampled three times in 2018, late May (spring), late July (summer), and mid-September (fall). Standard bottom-set gill nets (1.5 $\mathrm{m} * 25 \mathrm{~m}$ ) with mesh sizes between 13.5 and $45 \mathrm{~mm}$ were used. Six series of eight gill nets were created. Two series were deployed at each location for each sampling season (Table 1). The nets were set in the morning, and collected $24 \mathrm{~h}$ later. The nets were set from the shore in a $90^{\circ}$ angle. Linked nets were $200 \mathrm{~m}$ in length, and sampling occurred between depths of $2 \mathrm{~m}$ and 40-60 m, covering both the epilimneon and hypolimneon. In the south of Lake Norsjø, maximum sampling depth was approximately $20 \mathrm{~m}$. Totally, 258 perch, 101 whitefish, and 173 charr were caught. The catches per season and location are compiled in Table 2. A sub-sample of 75 perch, 75 charr, and 50 whitefish was randomly selected for further analysis.

\section{Fish}

The fish were frozen individually in labelled plastic bags until analyzed. After thawing, the fish were measured to the nearest $\mathrm{mm}$, and weighted to the closest gram. Otoliths were removed for age determination. The otoliths were burned over a propane stove, and divided using a scalpel. Age was determined under a stereo 
Table I. Mesh sizes of gill nets used at the study locations.

\begin{tabular}{lcccccccc}
\hline Location & \multicolumn{7}{c}{ Mesh size $(\mathrm{mm})$} \\
\hline North & 21 & 21 & 26 & 29 & 29 & 30 & 35 & 39 \\
North & 21 & 21 & 26 & 29 & 29 & 35 & 39 & 45 \\
Mid & 21 & 21 & 26 & 26 & 29 & 29 & 35 & 45 \\
Mid & 21 & 21 & 26 & 29 & 29 & 32 & 35 & 45 \\
South & 16.5 & 21 & 21 & 29 & 29 & 39 & 39 & 45 \\
South & 13.5 & 21 & 21 & 21 & 29 & 32 & 36 & 39 \\
\hline
\end{tabular}

Table 2. Fish catches per season and location.

\begin{tabular}{|c|c|c|c|}
\hline Species & Location & Season & Catch \\
\hline Arctic charr & North & Spring & 30 \\
\hline \multirow[t]{5}{*}{ (Salvelinus alpinus) } & North & Summer & 30 \\
\hline & North & Fall & 30 \\
\hline & Midt & Spring & 23 \\
\hline & Midt & Summer & 30 \\
\hline & Midt & Fall & 30 \\
\hline European whitefish & North & Spring & 30 \\
\hline \multirow[t]{8}{*}{ (Coregonus lavaretus) } & North & Summer & 23 \\
\hline & North & Fall & 14 \\
\hline & Midt & Spring & 7 \\
\hline & Midt & Summer & 11 \\
\hline & Midt & Fall & 6 \\
\hline & South & Spring & 2 \\
\hline & South & Summer & 5 \\
\hline & South & Fall & 3 \\
\hline European perch & North & Spring & 21 \\
\hline \multirow[t]{8}{*}{ (Perca fluviatilis) } & North & Summer & 30 \\
\hline & North & Fall & 30 \\
\hline & Midt & Spring & 27 \\
\hline & Midt & Summer & 30 \\
\hline & Midt & Fall & 30 \\
\hline & South & Spring & 30 \\
\hline & South & Summer & 30 \\
\hline & South & Fall & 30 \\
\hline
\end{tabular}

microscope at 40x magnification by counting opaque winter zones. Approximately $2 \mathrm{~g}$ of skeletal muscle was sampled below the dorsal fin of the fish. Muscle samples were freeze-dried for approximately 24 h using a Heto LyoLab 3000 (Heto-Holten A/S, Allerod, DK) freeze drier, and subsequently ground to fine powder using mortar and pestle. About $2 \mathrm{mg}$ of the freeze-dried powder of each fish was weighted, and placed in a tin capsule before sent to the Norwegian Institute for Energy Technology (IFE) for determination of stable isotope ratios of carbon and nitrogen $\left(\delta^{13} \mathrm{C}\right.$ and $\left.\delta^{15} \mathrm{~N}\right)$. At IFE, the samples were combusted in the presence of $\mathrm{O}_{2}$ and $\mathrm{Cr}_{2} \mathrm{O}_{3}$ at $1700{ }^{\circ} \mathrm{C}$ in a NCS 2500 elemental analyzer (Thermo Fisher Scientific, Waltham, MA, USA). $\mathrm{NO}_{\mathrm{x}}$ was reduced to $\mathrm{N}_{2}$ in a $\mathrm{Cu}$ oven at $650{ }^{\circ} \mathrm{C} . \mathrm{H}_{2} \mathrm{O}$ was removed in a chemical trap of $\mathrm{Mg}\left(\mathrm{ClO}_{4}\right)_{2}$ before separation of $\mathrm{N}_{2}$ and $\mathrm{CO}_{2}$ on a 2 m Poraplot Q GC column (Agilent J\&W, Santa Clara, CA, USA). $\mathrm{N}_{2}$ and $\mathrm{CO}_{2}$ were directly injected on-line to a DeltaXP plus isotope ratio mass spectrometer (IRMS) (Thermo Fisher Scientific, Waltham, MA, USA) to determine $\delta^{13} \mathrm{C}$ and $\delta^{15} \mathrm{~N}$ along with the $\mathrm{C} / \mathrm{N}$ ratio.

\section{Parasites}

The fish were visually examined for the presence of metazoan ectoparasites, especially on the gills and fins, in the field just after the fish had been taken out of the gillnets. Sampled ectoparasites were stored in labelled glass vials containing 96\% ethanol. Endoparasites were sampled in thawed fish in the laboratory. For endoparasite sampling, fish were opened from gills to anus. All cysts containing a cestode plerocercoid on the intestinal tract and other tissue were registered. A sample of encysted parasites was identified prior to the removal of organs. The intestinal tract was subsequently removed and placed in a petri dish in $9 \%$ saline solution. Saline solution was used to prevent parasites from disintegrating, which is common for cestodes in freshwater. The intestinal tract was cut open from oesophagus to anus, and all macroscopic parasites were collected. All parasites were identified according to morphological features under a stereomicroscope at 20-240x magnification. The number of cestodes was based on the number of heads (scolexes). The genera Argulus Müller, 1785, Triaenophorus Rudolphi, 1793, Eubothrium Nybelin, 1922, and Proteocephalus Weinland, 1858 were identified according to Bykhovskaya-Pavlovskaya et al. (1964). Salmincola Wilson, 1915 was identified according to Kabata (1969). Plerocercoid specimen of Dibothriocephalus Lühe, 1899 (formerly Diphyllobothrium Cobbold, 1858, revised genus name according to Waeschenbach et al. (2017)) were identified using Bykhovskaya-Pavlovskaya et al. (1964) and Andersen and Gibson (1989). It has to be noted, that Andersen and Gibson (1989) has some uncertainties related to frozen samples, as morphological features become less clear.

\section{Data analysis}

For all numerical variables describing fish metrics, mean, median, standard deviation and range were calculated. Prevalence and mean abundance of each parasite species were calculated according to Bush et al. (1997). Eubothrium salvelini (Schrank, 1790), Proteocephalus sp., Dibothriocephalus dendriticus (Nitzsch, 1824) Lühe, 1899, Dibothriocephalus ditremus (Creplin, 1825) Lühe, 1899, and Triaenophorus nodulosus (Pallas, 1781) were additionally pooled as copepod transmitted parasites, and prevalence and mean abundance was calculated for this group. D. dendriticus, D. ditremus, and T. nodulosus were pooled as plerocercoid larvae of cestodes, and prevalence and mean abundance calculated.

For each parasite group or species with a prevalence above $10 \%$, the abundance was modelled. Due to highly aggregated distributions of parasites, negative binomial generalized linear models were used (Wilson \& Grenfell 1997). The models were created using the glmmTMB-package (Brooks et al. 2017) in R (R Developer Core Team 2019). First, separate negative binomial generalized linear models using each of the following variables as explanatory variables were created. The candidate variables were length, weight, age, $\delta^{13} \mathrm{C}, \delta^{15} \mathrm{~N}, \mathrm{C} / \mathrm{N}$-ratio, sex, location, and season. The AIC for all of these models was calculated using the AIC-function in R ( $\mathrm{R}$ Developer Core Team 2019). The model with the lowest AIC was selected for further analysis. Subsequently, it was attempted to add one additional explanatory variable to the selected model. Extended models were created using the selected model, adding each of the remaining explanatory variables to separate models. The extended models were compared to the original model one by one, using maximum likelihood. This step was included to avoid selecting more complicated models with marginally lower AIC over the most 
parsimonious model. The AIC was calculated for the original model, and for each extended model that was significantly better than the original model according to maximum likelihood. The model with the lowest AIC was selected. The model selection process for each individual model is elaborated in Appendix 1. The residuals of the selected model were checked using simulated residuals in the DHARMa-package in R (R Developer Core Team 2019). Graphs of the model results were created using the ggplot2-package (Wickham 2016), and the ggeffects-package (Lüdecke 2018). Some of the selected models exhibited curved patterns in the residuals, and were thus not viable. In these cases, quadratic terms for numerical variables were used. The numerical variables length, weight, age, $\delta^{13} \mathrm{C}, \delta^{15} \mathrm{~N}$, and the $\mathrm{C} / \mathrm{N}$-ratio were included in new models as quadratic terms in the form $a X^{2}+b X$, where $X$ is the respective numerical variable, and $a$ and $b$ are coefficients, using the poly-function in $\mathrm{R}$ ( $\mathrm{R}$ Developer Core Team 2019). These models were selected, advanced, and checked in the same manner as the models using linear terms. For all tests, a significance level of $\alpha=0.05$ was used.

\section{RESULTS}

\section{Descriptive statistics}

Whitefish exhibited an average length of $279.2 \mathrm{~mm}$, and average weight of $198.7 \mathrm{~g}$, and a median weight of $177.0 \mathrm{~g}$ (Table 3). The average age of whitefish was 4.9 yrs. Whitefish had intermediate $\delta^{13} \mathrm{C}$-signatures (average $-28.3 \%$ ), and the lowest $\delta^{15} \mathrm{~N}$-signatures (average $8.0 \%$ ). The average length of charr was $272.5 \mathrm{~mm}$, at an average weight of $231.2 \mathrm{~g}$, and a median weight of $170.0 \mathrm{~g}$. Charr had an average age of 12.0 yrs. Charr exhibited the most negative $\delta^{13} \mathrm{C}$ signatures (average -29.4\%o), and the highest $\delta^{15} \mathrm{~N}$-signatures (average $11.5 \%$ ). Perch had an average length of $212.2 \mathrm{~mm}$, and an average weight of $141.3 \mathrm{~g}$, with a median weight of $83 \mathrm{~g}$. On average, perch was 4.2 yrs of age. Perch exhibited the least negative $\delta^{13} \mathrm{C}$-signatures (average -24.9\%), and intermediate $\delta^{15} \mathrm{~N}$-signatures (average 9.0 $\% 0)$. Age and size distributions and growth curves are presented in Appendix 2.

\section{Parasite species occurrence, prevalence and mean abundance}

In Whitefish in Lake Norsjø, Trematoda Rudolphi, 1808, Dibothriocephalus spp., Proteocephalus sp., Acanthocephala Koelreuter, 1771, Argulus coregoni Thorell, 1865, Salmincola sp., and Nematoda (Diesing, 1861) were found. Trematodes, and nematodes were only found in whitefish. The most prevalent parasites in whitefish were acanthocephalans (Prevalence: 36\%, mean abundance: 4.4) (Table 4) and Proteocephalus sp. (Prevalence: 24\%, mean abundance: 0.7).

In charr, A. coregoni, Salmincola edwardsii (Olsson, 1869), E. salvelini, T. nodulosus, D. ditremus, D. dendriticus, Proteocephalus sp., and acanthocephalans were identified. S. edwardsii, and E. salvelini were only found in charr. In charr, encysted parasites (plerocercoids) had a prevalence of $93 \%$, and a mean abundance of 20.2. E. salvelini was the most prevalent species (Prevalence: $68 \%$, mean abundance: 2.6 ), followed by $D$. ditremus with a prevalence of $43 \%$, and a mean abundance of 1.0 .

Perch was infected with T. nodulosus, Eubothrium sp., Dibothriocephalus spp., Proteocephalus sp., and acanthocephalans. No parasite species was exclusively found in perch. Perch was mainly infected by acanthocephalans with a prevalence of $79 \%$, and a mean abundance of 4.7 .

\section{Abundance}

In whitefish, the abundance of Proteocephalus sp., Acanthocephalans, A. coregoni, Salmincola sp., and copepod transmitted parasites were modelled. The abundance of $A$. coregoni in whitefish varied by season with significantly higher abundance in the summer (Table 5). Season was also included in the model for Salmincola sp. in whitefish, with no apparent seasonal patterns. The abundance of Proteocephalus sp. in

Table 3. Descriptive statistics of numerical fish properties of fish selected for parasite sampling.

\begin{tabular}{|c|c|c|c|c|c|}
\hline Species & Variable & Mean & Median & $\mathrm{SD}$ & Range \\
\hline \multirow[t]{6}{*}{ European whitefish (Coregonus lavaretus) } & Length (mm) & 279.2 & 282.5 & 47.4 & $186-440$ \\
\hline & Weight (g) & 198.7 & 177.0 & 120.0 & $47-757$ \\
\hline & Age (yrs) & 4.9 & 4.5 & 2.1 & $2-9$ \\
\hline & $\mathrm{d}^{13} \mathrm{C}(\%)$ & -28.3 & -28.6 & 2.3 & $-31.3--21.8$ \\
\hline & $\mathrm{d}^{15} \mathrm{~N}(\%)$ & 8.0 & 8.3 & 2.3 & $3.6-12.3$ \\
\hline & $\mathrm{C} / \mathrm{N}$ ratio & 3.2 & 3.2 & 0.1 & $3.1-3.4$ \\
\hline \multirow[t]{6}{*}{ Arctic charr (Salvelinus alpinus) } & Length (mm) & 272.5 & 259.0 & 62.9 & $153-438$ \\
\hline & Weight (g) & 231.2 & 170.0 & 188.3 & $28-981$ \\
\hline & Age (yrs) & 12.0 & 10.0 & 6.6 & $4-31$ \\
\hline & $\mathrm{d}^{13} \mathrm{C}(\% 0)$ & -29.4 & -29.5 & 1.1 & $-32.1--27.1$ \\
\hline & $\mathrm{d}^{15} \mathrm{~N}(\%)$ & 11.5 & 11.6 & 1.8 & $6.61-14.8$ \\
\hline & $\mathrm{C} / \mathrm{N}$ ratio & 3.4 & 3.4 & 0.2 & $3.1-4.4$ \\
\hline \multirow[t]{6}{*}{ European perch (Perca fluviatilis) } & Length (mm) & 212.2 & 197.0 & 55.1 & $112-356$ \\
\hline & Weight (g) & 141.3 & 83.0 & 141.3 & $13-633$ \\
\hline & Age (yrs) & 4.2 & 4 & 1.7 & $1-10$ \\
\hline & $\mathrm{d}^{13} \mathrm{C}(\%)$ & -24.9 & -25.1 & 2.5 & $-29.6--19.3$ \\
\hline & $\mathrm{d}^{15} \mathrm{~N}(\%)$ & 9.0 & 9.2 & 1.5 & $5.6-12.2$ \\
\hline & $\mathrm{C} / \mathrm{N}$ ratio & 3.2 & 3.2 & 0.05 & $3.1-3.4$ \\
\hline
\end{tabular}


Table 4. The parasites prevalence and mean abundance in their hosts.

\begin{tabular}{|c|c|c|c|}
\hline Host species & Parasite species/group & Prevalence $(\%)$ & Mean abundance \\
\hline \multirow[t]{9}{*}{ European whitefish (Coregonus lavaretus) } & Trematoda & 2 & 0.1 \\
\hline & Argulus coregoni & 20 & 0.4 \\
\hline & Salmincola sp. & 12 & 0.1 \\
\hline & Dibothriocephalus spp. & 4 & 0.0 \\
\hline & Proteocephalus sp. & 24 & 0.7 \\
\hline & Acanthocephala & 36 & 4.4 \\
\hline & Nematoda & 2 & 0.0 \\
\hline & Copepod transmitted & 28 & 0.7 \\
\hline & Plerocercoids & 4 & 0.0 \\
\hline \multirow[t]{11}{*}{ Arctic charr (Salvelinus alpinus) } & Argulus coregoni & 1.33 & 0.0 \\
\hline & Salmincola edwardsii & 16 & 0.2 \\
\hline & Cysts (Plerocercoids) & 93 & 20.2 \\
\hline & Eubothrium salvelini & 68 & 2.6 \\
\hline & Triaenophorus nodulosus & 36 & 0.6 \\
\hline & Dibothriocephalus ditremus & 43 & 1.0 \\
\hline & Dibothriocephalus dendriticus & 25 & 0.3 \\
\hline & Proteocephalus sp. & 7 & 0.3 \\
\hline & Acanthocephala & 3 & 0.0 \\
\hline & Copepod transmitted & 99 & 24.9 \\
\hline & Plerocercoids & 99 & 22.0 \\
\hline \multirow[t]{7}{*}{ European perch (Perca fluviatilis) } & Triaenophorus nodulosus & 4 & 0.0 \\
\hline & Eubothrium sp. & 3 & 0.0 \\
\hline & Dibothriocephalus spp. & 4 & 0.1 \\
\hline & Proteocephalus sp. & 5 & 0.1 \\
\hline & Acanthocephala & 79 & 4.7 \\
\hline & Copepod transmitted & 12 & 0.2 \\
\hline & Plerocercoids & 7 & 0.1 \\
\hline
\end{tabular}

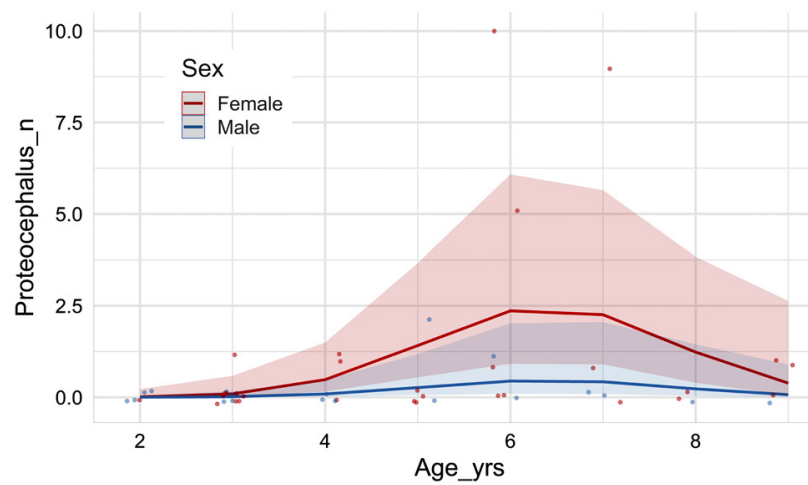

Figure 2. The abundance of Proteocephalus sp. in whitefish depending on the age of the host.

whitefish was affected by sex, with significantly higher abundances in females (Figure 2). The relationships between age and the abundance of Proteocephalus sp., Acanthocephalans (Figure 3), and copepodtransmitted parasites (Figure 4) in whitefish were all significant and quadratic, with the highest abundances found between the age of 5 and 8 years.

For charr, models were created for the parasites and groups S. edwardsii, encysted parasites (plerocercoids), E. salvelini, $T$. nodulosus, D. ditremus, D. dendriticus, plerocercoids, and copepod transmitted parasites. Age was included in the model of the abundance of $S$. edwardsii in charr, but no significant correlation or trend was found. The abundance of encysted parasites (plerocercoids) was significantly positively correlated to age in charr (Figure 5). This was also the case for the abundance of E. salvelini in charr. It was also a tendency towards higher abundances in the spring, although not significant (Figure 6). The abundance of T. nodulosus in charr tends to increase by age, but not significantly. $D$. ditremus in charr depended on sex, with significantly higher abundances in male fish. The abundance of $D$. dendriticus in charr varied by season, with significantly fewer individuals found in the fall. The abundance of plerocercoids in charr increased significantly by length, and had a non-significant tendency to decrease by age (Figure 7). In charr, the abundance of copepod transmitted parasites increased significantly by length, with a non-significant tendency to decrease by age (Figure 8).

Acanthocephalans, and copepod transmitted parasites were modelled in perch. In perch, the abundance of acanthocephalans varied by season, with significantly fewer individuals found in the fall. In addition, there was a positive trend of acanthocephalans by $\delta^{15} \mathrm{~N}$, which was not significant. The abundance of copepod transmitted parasites in perch depended on age following a quadratic equation, with the highest abundances at age $>6$ (Figure 9). 


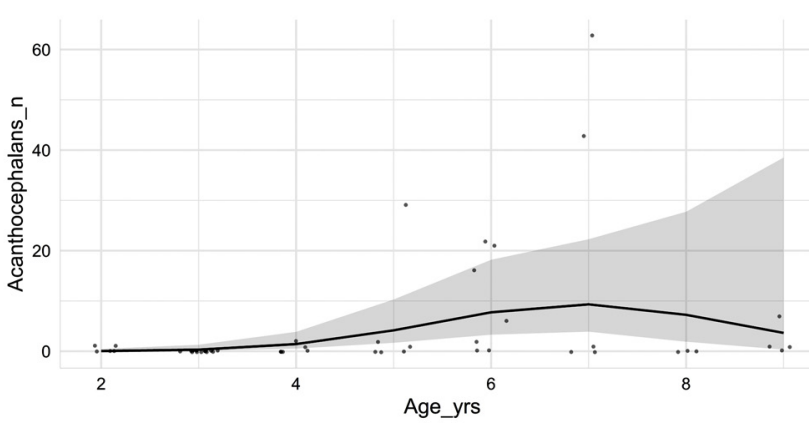

Figure 3. The abundance of acanthocephalans in whitefish depending on the age of the host.

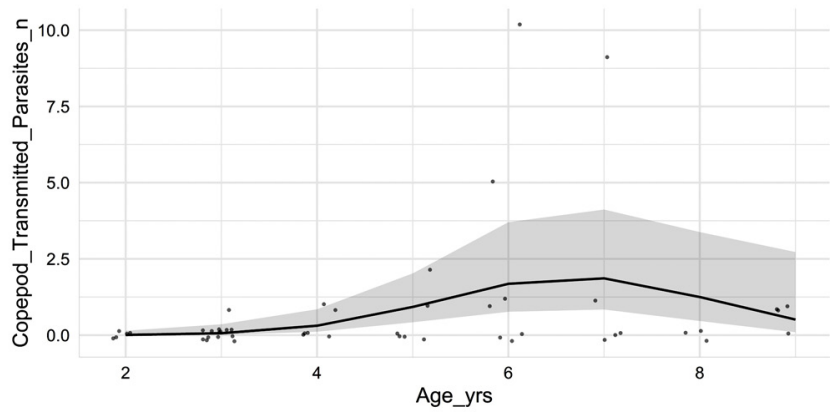

Figure 4. The abundance of copepod transmitted parasites in whitefish depending on the age of the host.

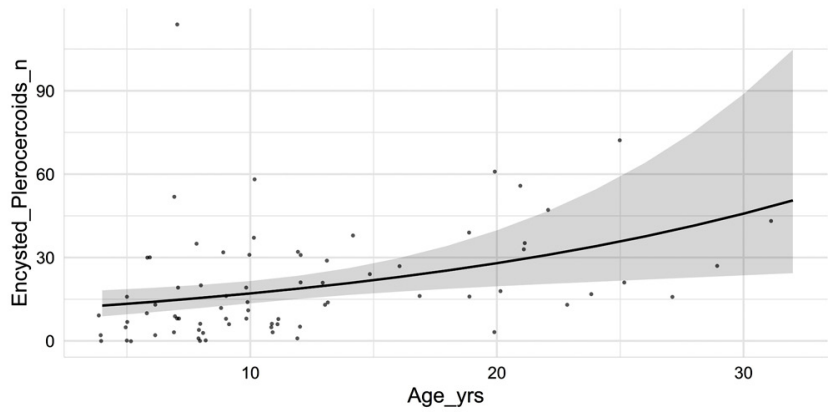

Figure 5. The number of encysted plerocercoid larvae of cestodes found in charr in relation to the age of the host.

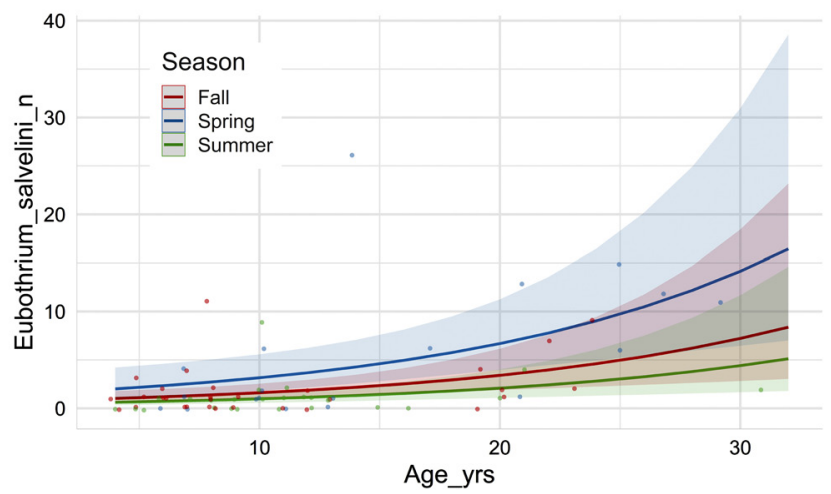

Figure 6. The number of Eubothrium salvelini found in charr depended on the age of the host and season.

\section{DISCUSSION}

Excepting the acanthocephalans and nematodes in whitefish, all the parasites found in our study have previously been described in

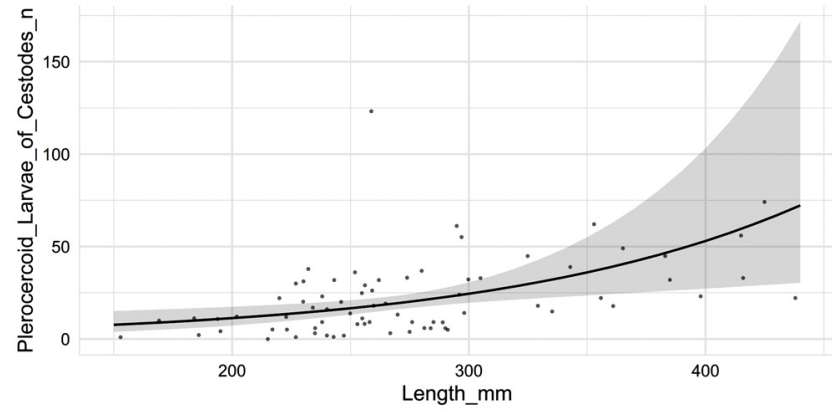

Figure 7. The number of plerocercoid larvae of cestodes in charr depending on the length of the host.

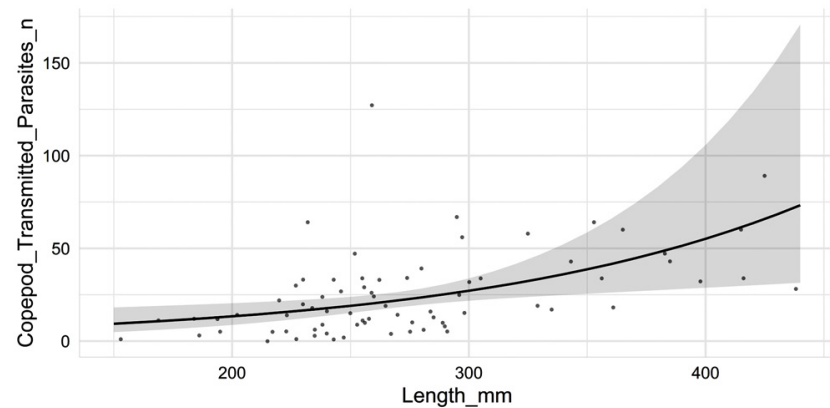

Figure 8. The length of charr was the best predictor for the abundance of copepod transmitted parasites in this species.

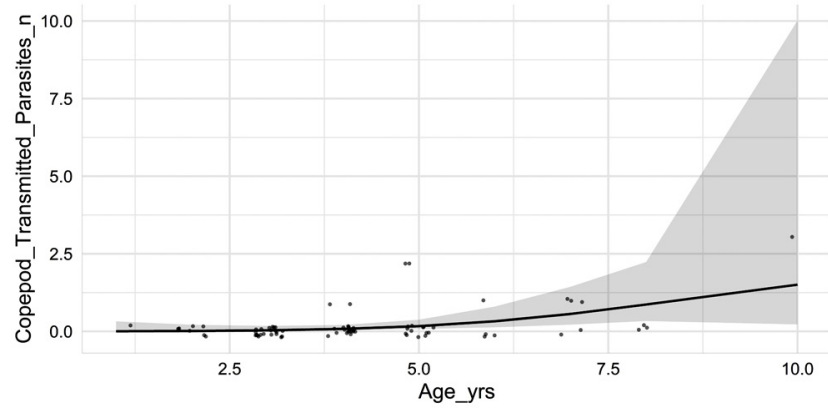

Figure 9. The number of copepod transmitted parasites found in perch depended on the age of the host.

Norway, and to parasitize the respective host species (Sterud 1999 and references therein). Acanthocephalans have been shown to parasitize whitefish in Italy (Dezfuli et al. 2009), the Bothnian Bay (Baltic Sea) (Wayland et al. 2004), and Finland (Karvonen \& Valtonen 2004), and nematodes are found in whitefish, for instance in Finland (Pulkkinen et al. 1999; Karvonen \& Valtonen 2004). These parasite groups may not have been found in whitefish in Norway before, as there are limited studies on parasites in southern Norway. The most common parasites found in our study depend on the general diet and habitat of the host species. Perch was mainly infected with Acanthocephalans, which are transmitted via ostracods, isopods or amphipods (Woo 2006). In Lake Norsjø, ostracods and the isopod Asellus aquaticus Linnaeus, 1758 have previously been found in stomach samples of fish (Olk et al. 2016). As these are benthic animals, the high occurrence of acanthocephalans in perch indicates a littoral diet. Perch has a high dependence on the littoral zone (Zamora \& Moreno-Amich 2002; Jacobsen et al. 2015), and it prefers the littoral zone during spring and summer according to a telemetric study (Westrelin et al. 2018). In whitefish, both Acanthocephalans and Proteocephalus sp. were the most common parasites. Proteocephalus sp. are transmitted by 
Table 5. Model results for macroparasite abundance in the host species Arctic charr (Salvelinus alpinus), European whitefish (Coregonus lavaretus), and European perch (Perca fluviatilis).

\begin{tabular}{|c|c|c|c|c|c|c|c|}
\hline Host & Parasite & Metric & Term & Estimate & SE & $\mathrm{z}$ & $\mathrm{p}$ \\
\hline European whitefish & Argulus coregoni & Season & $\Delta$ spring & -20.234 & 17083.729 & -0.001 & $>0.1$ \\
\hline \multirow[t]{10}{*}{ (Coregonus lavaretus) } & & & $\Delta$ summer & 2.249 & 1.111 & 2.024 & $<0.05$ \\
\hline & Salmincola sp. & Season & $\Delta$ spring & 21.07 & 27213.70 & 0.001 & $>0.1$ \\
\hline & & & $\Delta$ summer & 20.88 & 27213.70 & 0.001 & $>0.1$ \\
\hline & Proteocephalus sp. & Sex & $\Delta$ male & -1.6702 & 0.8506 & -1.964 & $<0.05$ \\
\hline & & Age & $\beta \mathrm{Age}^{2}$ & -8.1682 & 2.9387 & -2.780 & $<0.01$ \\
\hline & & & $\beta$ Age & 8.8081 & 3.5408 & 2.488 & $<0.05$ \\
\hline & acanthocephala & Age & $\beta \mathrm{Age}^{2}$ & -6.3996 & 2.7692 & -2.311 & $<0.05$ \\
\hline & & & $\beta$ Age & 10.2080 & 3.0930 & 3.300 & $<0.001$ \\
\hline & copepod transmitted & Age & $\beta \mathrm{Age}^{2}$ & -7.2901 & 2.6623 & -2.738 & $<0.01$ \\
\hline & & & $\beta$ Age & 9.9698 & 3.4119 & 2.922 & $<0.01$ \\
\hline Arctic charr & Salmincola edwardsii & Age & $\beta$ Age & 0.02457 & 0.04639 & -0.530 & $>0.1$ \\
\hline \multirow[t]{12}{*}{ (Salvelinus alpinus) } & encysted plerocercoids & Age & $\beta$ Age & 0.04927 & 0.01784 & 2.762 & $<0.01$ \\
\hline & Eubothrium salvelini & Age & $\beta$ Age & 0.07495 & 0.02265 & 3.309 & $<0.001$ \\
\hline & & Season & $\Delta$ spring & 0.67294 & 0.35945 & 1.872 & $>0.05$ \\
\hline & & & $\Delta$ summer & -0.49272 & 0.36182 & -1.362 & $>0.1$ \\
\hline & Triaenophorus nodulosus & Age & $\beta$ Age & 0.03862 & 0.02962 & 1.304 & $>0.1$ \\
\hline & Dibothriocephalus ditremus & Sex & $\Delta$ male & 0.7419 & 0.3685 & 2.014 & $<0.05$ \\
\hline & Dibothriocephalus dendriticus & Season & $\Delta$ spring & 1.5041 & 0.6667 & 2.256 & $<0.05$ \\
\hline & & & $\Delta$ summer & 1.3863 & 0.6583 & 2.106 & $<0.05$ \\
\hline & plerocercoids & Length & $\beta$ Length & 0.007730 & 0.002632 & 2.937 & $<0.01$ \\
\hline & & Age & $\beta$ Age & 0.009221 & 0.024309 & -0.379 & $>0.1$ \\
\hline & copepod transmitted & Length & $\beta$ Length & $7.088 * 10^{-3}$ & $2.57 * 10^{-3}$ & 2.758 & $<0.01$ \\
\hline & & Age & $\beta A g e$ & $-5.728 * 10^{-5}$ & $2.367 * 10^{-2}$ & -0.002 & $>0.1$ \\
\hline European perch & acanthocephala & Season & $\Delta$ spring & 1.00851 & 0.37483 & 2.691 & $<0.01$ \\
\hline \multirow[t]{4}{*}{ (Perca fluviatilis) } & & & $\Delta$ summer & 1.41060 & 0.38679 & 3.647 & $<0.001$ \\
\hline & & $\delta^{15} \mathrm{~N}$ & $\beta \delta^{15} \mathrm{~N}$ & 0.13224 & 0.09457 & 1.398 & $>0.1$ \\
\hline & copepod transmitted & Age & $\beta \mathrm{Age}^{2}$ & -1.8552 & 2.7481 & 0.675 & $>0.1$ \\
\hline & & & $\beta$ Age & 10.1687 & 4.0685 & 2.409 & $<0.05$ \\
\hline
\end{tabular}

copepods (Scholz 1999). This indicates, that whitefish in Lake Norsjø feed on both pelagic and littoral resources. Charr was mainly infected by copepod transmitted parasites, indicating a pelagic diet. However, sampling was conducted relatively close to the shore, meaning that charr was found below the littoral zone, but not necessarily in the open waters of the pelagic zone. Charr was not found in the pelagic zone of Lake Norsjø during a previous survey (Sandlund et al. 2016). This is also supported by the $\delta^{13} \mathrm{C}$-signatures, which were most negative for charr, followed by whitefish. The least negative $\delta^{13} \mathrm{C}$-signatures were found in perch. Stable isotope signatures are used to trace energy flow $\left(\delta^{13} \mathrm{C}\right)$ and trophic position $\left(\delta^{15} \mathrm{~N}\right)$ in food webs (Peterson \& Fry 1987; Cabana \& Rasmussen 1996; Post 2002). Heavier isotopes form more stable bonds, and compounds including lighter isotopes are more readily metabolized (Hoefs 2013). As a consequence, $\delta^{15} \mathrm{~N}$ increases on average with $3.4 \%$ per trophic level (Minagawa \& Wada 1984; Post 2002), and $\delta^{13} \mathrm{C}$ can be used to trace the dietary carbon source (Post 2002). The stable isotope signature of carbon $\left(\delta^{13} \mathrm{C}\right)$ averagely varies with habitat. Littoral signatures are generally less negative than pelagic or profundal signatures (Vander Zanden \& Rasmussen 1999).
While the occurrence of the most common parasites depends on the dietary niche of the respective species, abundance of the individual parasite species in individual host species was found to depend on sex, age, length, season and trophic levels measured as $\delta^{15} \mathrm{~N}$ in our study. A. coregoni had a higher abundance in the summer in whitefish than in the other seasons. This matches the seasonal occurrence of $A$. coregoni, as found in several studies on the parasite in aquaculture (Shimura 1983; Hakalahti \& Valtonen 2003; Hakalahti et al. 2004b). A. coregoni overwinters as eggs (Shimura 1983), and eggs are not able to develop and hatch at temperatures below $8-10{ }^{\circ} \mathrm{C}$ (Mikheev et al. 2001; Hakalahti \& Valtonen 2003). When temperatures exceed this critical value, eggs hatch over an extended period (Hakalahti et al. 2004a), from May to July (Shimura 1983), or during early summer (Hakalahti \& Valtonen 2003). From July onwards, female A. coregoni detach from their fish hosts to lay eggs (Hakalahti \& Valtonen 2003), and egg laying proceeds from mid-July to mid-October (Hakalahti et al. 2004b). Consequently, the highest abundance of $A$. coregoni on its host whitefish was found in the summer.

The abundance of Proteocephalus sp. in whitefish was highest 
in fish aged 5-8 yrs, and in females. Whitefish between the age of 5 and 8 yrs may have consumed higher numbers of copepods. This is also supported by the higher abundance of copepod transmitted parasites in whitefish aged 5-8 yrs in Lake Norsjø. However, stomach contents have not been analyzed in our study. Higher abundance of Proteocephalus percae (Müller, 1780) in females has previously been demonstrated in perch during the spawning season (Balling \& Pfeiffer 1997). However, the higher abundance of Proteocephalus sp. in female whitefish in Lake Norsjø did not differ by season, and may have been caused by a different mechanism. Acanthocephalans were also most abundant in whitefish between the age of 5 and 8 yrs, meaning that whitefish between the age of 5 and 8 yrs may also consume more amphipods, isopods and ostracods (Woo 2006). In addition, acanthocephalans can be transmitted by predation on fish (Woo 2006), and since whitefish aged 5-8 yrs are towards the older end of the ages recorded, these whitefish may consume some fish.

Charr was infected by a variety of parasites in our study, most of which copepod transmitted. The abundance of the ectoparasite S. edwardsii showed no apparent relationship to the age of the fish, even though age was included in the model. S. edwardsii directly infects its host, and its abundance is not affected by the diet (Kabata 1969). Infective copepodids of $S$. edwardsii are usually found towards the bottom of the lake (Poulin et al. 1990), indicating that charr utilizes benthic habitat. Our results are different from previous studies, which indicate a greater risk of infection with S. edwardsii with increasing size and age of the host (Black et al. 1983; Amundsen et al. 1997). In addition, host size is suggested to be the most important predictor of ectoparasite loads, as larger fish represent larger targets for the parasite, and more water is circulated over the gills of large fish (Poulin et al. 1991). However, usually $S$. edwardsii is found to infect the gill region (Conley \& Curtis 1993; Amundsen et al. 1997), while it was found in other microhabitats in our study. The parasite was found attached to the skin and fins in our study, which has previously been observed in small fish (Black et al. 1983; Conley \& Curtis 1993). This may result in the more uniform distribution of the parasite related to age in charr. However, attachment to the fins may also be a local adaption of the parasite (Amundsen et al. 1997), as the fins were the exclusive attachment site in a study on S. edwardsii in Ennerdale Water in Britain (Fryer 1981). The abundance of encysted parasites (plerocercoids) in charr was positively correlated to the age of the host. Encysted parasites belong to a variety of species, and in general, parasite abundance is shown to increase by age (Khan 2012), as long lived hosts provide a more stable habitat for parasites, and may accumulate parasites over time (Bell \& Burt 1991). The abundance of E. salvelini was also positively correlated with the age of charr, and it is specifically shown to accumulate with age (Smith 1973; Hanzelová et al. 2002). This parasite is host-specific to charr in Europe, and has a life-cycle using copepods as intermediate host, and charr as definite host (Andersen $\&$ Kennedy 1983). Low infection rates in copepods (0.001-0.002\%) are common for E. salvelini (Boyce 1974; Hanzelová et al. 2002). Thus, the high prevalence of this parasite in charr in Lake Norsjø could indicate heavy feeding on copepods. However, as this parasite may alter the behavior of copepods, charr may selectively feed on infected copepods, and this may also explain high abundances in fish (Poulin et al. 1992). E. salvelini was more abundant in the spring in our study, although not significantly so. Previously, no seasonal variation in abundance are reported for this parasite (Hoffmann et al. 1986a; Hernandez \& Muzzall 1998; Hanzelová et al. 2002), as they continuously emit eggs (Hanzelová et al. 2002). However, peaks in egg shedding are reported in the spring (Boyce 1974; Kennedy 1978;
Hernandez \& Muzzall 1998), which may cause seasonal variations in E. salvelini in Lake Norsjø. However, peaks in egg shedding in the spring do not cause higher abundances of the parasite observed in fish the same spring, as more time is needed for E. salvelini to infect copepods, to be consumed by fish, and to establish in fish to the point that the parasite is visible to the unaided eye.

Plerocercoid larvae of cestodes were found to increase in abundance by length in charr in our study. Specifically, plerocercoid larvae of $T$. nodulosus, $D$. ditremus, and $D$. dendriticus were identified. The increase in abundance by size is likely caused by accumulation of plerocercoids over time. Triaenophorus sp. is able to survive in its intermediate fish host for several years, and thus able to accumulate with increasing size or age (Dick \& Rosen 1982; Rosen \& Dick 1984; Hoffmann et al. 1986b). This is also reflected in the individual trend of increasing abundance of T. nodulosus by age in our study. Dibothriocephalus spp. also survives in their intermediate fish hosts for several years, and may accumulate (Halvorsen \& Andersen 1984; Henriksen et al. 2016). In addition, Dibothriocephalus spp. may re-establish in predatory fish (Hammar 2000; Henriksen et al. 2016), and feeding on smaller infected fish may result in higher abundances of Dibothriocephalus spp. in larger charr. In Lake Norsjø, three-spined sticklebacks and European smelt are present (Jensen 1954), which are both intermediate hosts for Dibothriocephalus spp. (Andersen et al. 1986; Andersen \& Valtonen 1992; Anikieva \& Ieshko 2017). D. ditremus also exhibited a higher abundance in male charr, with no apparent relationship between sex and any other variable that could explain the higher occurrence of $D$. ditremus in males. As the reasons behind this remain obscure, this may be caused by feeding specialization of male charr on the infected copepod species. Charr exhibit individual feeding-specialization, and are persistent in their diet over long periods (Knudsen et al. 2004, 2009). The abundance of $D$. dendriticus exhibited seasonal variations, with fewer specimen found in the fall. This is also unusual, as the parasite lives for several years in fish (Halvorsen \& Andersen 1984), and other studies show no significant seasonal variations in its abundance (Henriksen et al. 2019). As the first intermediate host of $D$. dendriticus are copepods (Halvorsen 1966; Marcogliese 1995; Scholz et al. 2009), seasonal trends may be linked to new infections and fluctuations in copepod abundance.

The abundance of copepod transmitted parasites in charr in general was positively correlated to fish length. Increases in parasite abundance with body size are common (Bell \& Burt 1991; Poulin 1995, 2000, 2004; Valtonen et al. 2010; Poulin \& Leung 2011; Timi et al. 2011; Timi \& Lanfranchi 2013; Anegg et al. 2014). Larger hosts provide a greater diversity of niches, more space for parasites (Poulin 1995; Poulin \& Leung 2011), and consume more potentially infected food (Poulin 1997).

In perch, acanthocephalans had a non-significant tendency to increase with trophic position measured as $\delta^{15} \mathrm{~N}$, and exhibited seasonal variations with lower abundance in the fall. Acanthocephalans are transmitted by isopods, amphipods and ostracods (Woo 2006), which is not necessarily consistent with higher trophic levels. However, generally more parasites are found at higher trophic levels (Luque \& Poulin 2008; Timi et al. 2011; Alarcos \& Timi 2012), and perch in Lake Norsjø may mainly feed on littoral benthic animals. Acanthocephalans are recruited in the spring, and live approximately one season (Woo 2006), which may result in fewer specimen remaining in the fall. The abundance of copepod transmitted parasites in perch was highest in fish older than 6 yrs. This may be a general positive relationship between parasite abundance and age of the host (Khan 2012), due to accumulation and a more stable habitat in long-living hosts (Bell \& Burt 1991). In addition, it may be caused by older perch consuming more pelagic prey, such as copepods in Lake Norsjø. However, this 
would need to be confirmed using stomach content analysis.

In Lake Norsjø, the host species, perch, whitefish and charr, exhibit different parasite communities, which could be related to their respective dietary niches. Habitat appeared to be important in defining which parasites were most prevalent in their respective hosts. Differences in parasite community by habitat have previously been found in charr (Henricson \& Nyman 1976; Frandsen et al. 1989; Dorucu et al. 1995; Knudsen et al. 1997; Siwertsson et al. 2016; Paterson et al. 2019) and whitefish (Knudsen et al. 2003; Karvonen et al. 2013). When modelling individual parasite abundances, increasing abundances by age and size of the fish host were most commonly found in our study.

\section{REFERENCES}

Alarcos AJ, Timi JT. 2012. Parasite communities in three sympatric flounder species (Pleuronectiformes: Paralichthyidae). Similar ecological filters driving toward repeatable assemblages. Parasitology Research 110: 2155-2166. doi: 10.1007/s00436-011-2741-5

Amundsen P-A, Kristoffersen R, Knudsen R., Klemetsen A. 1997. Infection of Salmincola edwarsii (Copepoda: Lernaeopodidae) in an age-structured population of Arctic charr - a long term study. Journal of Fish Biology 51: 1033-1046. doi: 10.1111/j.1095-8649.1997.tb01542.x

Andersen K. 1978. The helmiths in the gut of perch (Perca fluviatilis L.) in a small oligotrophic lake in southern Norway. Zeitschrift für Parasitenkunde 56: 17-27. doi: 10.1007/bf00925933

Andersen K, Kennedy C. 1983. Systematics of the Genus Eubothrium Nybelin (Cestoda, Pseudophyllidae), with Partial Re-description of the Species. Zoologica Scripta 12: 95-105. doi: 10.1111/j.1463-6409.1983. tb00554.x

Andersen K, Lei Ching H, Vik R. 1986. A review of freshwater species of Diphyllobothrium with redescriptions and the distribution of $D$. dendriticum (Nitzsch, 1824) and D. ditremum (Creplin, 1825) from North America. Canadian Journal of Zoology 65: 2216-2228. doi: 10.1139/z87-336

Andersen K, Valtonen E. 1992. Segregation and co-occurrence of larval cestodes in freshwater fishes in the Bothnian Bay, Finland. Parasitology 104: 161-168. doi: 10.1017/S003118200006090X

Andersen KI, Gibson DI. 1989. A key to the three species of larval Diphyllobothrium Cobbold, 1858 (Cestoda Pseudophyllidea) occurring in European and North American freshwater fishes. Systematic Parasitology 13: 3-9. doi: 10.1007/BF00006946

Anegg P, Psenner R, Tartarotti B. 2014. Infestation of zooplankton with Triaenophorus and Proteocephalus procercoids (Cestoda) in a deep oligotrophic lake. Journal of Limnology 74: 40-49. doi: 10.4081/ jlimnol.2014.1021

Anikieva L, Ieshko E. 2017. An annotated species list of parasites found in European smelt, Osmerus eperlanus (L.). Proceeding of research KRC RAS 7: 73 - 92. doi: 10.17076/bg627

Balling TE, Pfeiffer W. 1997. Frequency distributions of fish parasites in the perch Perca fluviatilis L. from Lake Constance. Journal of Parasitology Research 83: 370-373. doi: 10.1007/s004360050264

Bell G, Burt A. 1991. The comparative biology of parasite species diversity: internal helminths of freshwater fish. Journal of Animal Ecology 60: 1047-1064. doi: 10.2307/5430

Bérubé M, Curtis MA. 1984. The Occurence of Diphyllobothrium ditremum in Arctic charr (Salvelinus alpinus) Populations in Two Small Lakes in Northern Quebec: A comparative Study. Spring meeting held at the University of Bristol, 4. - 6. April 1984 Bristol. British Society for Parasitology Proceedings.

Black GA, Montgomery L, Whoriskey F. 1983. Abundance and distribution of Salmincola edwarsii (Copepoda) on anadromous brook trout, Salvelinus fontinalis, (Mitchill) in the Moisie River System, Quebec. Journal of Fish Biology 22: 567-575. doi: 10.1111/j.1095- 8649.1983.tb04216.x

Borgström R, Lien L. 1973. Studies of the Helminth Fauna of Norway XXX: Description of Proteocephalus sp. Weinland, 1858 (Cestoda:Proteocephala) in Brown Trout, Salmo trutta L., from Southern Norway. Norwegian Journal of Zoology 21: 289-291.

Boyce NPJ. 1974. Biology of Eubothrium salvelini (Cestoda: Pseudophyllidea), a Parasite of Juvenile Sockeye Salmon (Oncorhynchus nerka) of Babine Lake, British Columbia. Journal of the Fisheries Research Board of Canada 31: 1735-1742. doi: 10.1139/f74-220

Brooks M, Kristensen K, Van Benthem K, Magnusson A, Berg CW, Nielsen A, Skaug H, Mächler M, Bolker B. 2017. glmmTMB Balances Speed and Flexibility Among packages for Zero-inflated Generalized Linear Mixed Modeling. The R Journal 9: 378-400. doi: 10.32614/ RJ-2017-066

Bush A, Aho J, Kennedy C. 1990. Ecological versus phylogenetic determinants of helminth parasite community richness. Ëvolutionary Ecology 4: 1-20. doi: 10.1007/BF02270711

Bush AO, Lafferty KD, Lotz JM, Shostak AW. 1997. Parasitology meets ecology on its own terms: Margolis et al. revisited. Journal of Parasitology 83: 575-583. doi: 10.2307/3284227

Bykhovskaya-Pavlovskaya IE, Gusev AV, Dubinina MN, Izyumova NA, Smirnova TS, Sokolovskaya IL, Shtein GA, Shulman SS, Epshtein VM. 1964. Key to Parasites of Freshwater Fish of the U.S.S.R., Washington D. C. Academy of Sciences of the U.S.S.R. Zoological institute.

Cabana G, Rasmussen JB. 1996. Comparison of aquatic food chains using nitrogen isotopes. Proceedings of the National Academy of Sciences 93: 10844-10847. doi: 10.1073/pnas.93.20.10844

Chen H-W, Liu W-C, Davis AJ, Jordán F, Hwang M-J, Shao K-T. 2008. Network position of hosts in food webs and their parasite diversity. Oikos 117: 1847-1855. doi: 10.1111/j.1600-0706.2008.16607.x

Conley DC, Curtis M. 1993. Larval development of the parasitic copepod Salmincola edwardsii on brook trout (Salvelinus fontinalis). Canadian Journal of Zoology 72: 154-159. doi: 10.1139/z94-019

Dezfuli BS, Lui A, Giovinazzo G, Boldrini P, Giari L. 2009. Intestinal inflammatory response of powan Coregonus lavaretus (Pisces) to the presence of acanthocephalan infections. Parasitology 136: 929-937. doi: $10.1017 / \mathrm{S} 0031182009006295$

Dick TA, Rosen R. 1982. Experimental infections of whitefish, Coregonus clupeaformis (Mitchill), with Triaenophorus crassus Forel. Journal of Fish Diseases 5: 83-86. doi: 10.1111/j.1365-2761.1982.tb00461.x

Dorucu M, Adams CE, Huntingford FA, Crompton DWT. 1995. How fish-helminth association arise: an example from Arctic charr in Loch Rannoch. Journal of Fish Biology 47: 1038-1043. doi: 10.1111/j.10958649.1995.tb06027.x

ESRI (Environmental Systems Research Institute) 2012. ArcGIS. Release 10.1 ed. Redlands, CA.

Frandsen F, Malmquist H, Snorrason S. 1989. Ecological parasitology of polymorphic Arctic charr, Salvelinus alpinus (L.), in Thingvallavatn, Iceland. Journal of Fish Biology 34: 281-297. doi: 10.1111/j.10958649.1989.tb03309.x

Fryer G. 1981. The copepod Salmincola edwardsii as a parasite of Salvelinus alpinus in Britain, and a consideration of so-called relict fauna of Ennerdale Water. Journal of Zoology, London 193: 253-268. doi: 10.1111/j.1469-7998.1981.tb03443.x

Hakalahti T, Häkkinen H, Valtonen ET. 2004a. Ectoparasitic Argulus coregoni (Crustacea: Branchiura) hedge their bets - studies on egg hatching dynamics. Oikos 107: 295-302. doi: 10.1111/j.00301299.2004.13213.x

Hakalahti T, Pasternak AF, Valtonen ET. 2004b. Seasonal dynamics of egg laying and egg-laying strategy of the ectoparasite Argulus coregoni (Crustacea: Branchiura). Parasitology 128: 655-660. doi: 10.1017/ S0031182004004986

Hakalahti T, Valtonen ET. 2003. Population structure and recruitment of the ectoparasite Argulus coregoni Thorell (Crustacea: Branchiura) on a fish farm. Parasitology 127: 79-85. doi: 10.1017/S0031182003003196 Halvorsen O. 1966. Studies of the helminth fauna of Norway. VIII. An 
experimental investigation of copepods as first intermediate hosts for Diphyllobothrium norvegicum Vik (Cestoda). Nytt Magasin for Zoologi 13: 83-117.

Halvorsen O. 1968. Studies of the helminth fauna of Norway. XII. Azygia ludi (Müller, 1776) (Digenea, Azygiidae) in pike (Esox lucius L.) from Bogstad Lake, and a note on its occurrence in lake and river habitats. Nytt Magasin for Zoologi 16: 29-38.

Halvorsen O. 1970. Studies of the helminth fauna of Norway XV: on the taxonomy and biology of plerocercoids of Diphyllobothrium Cobbold, 1858 (Cestoda, Pseudophyllidea) from north-western Europe. Nytt Magasin for Zoologi 18: 113-174.

Halvorsen O. 1972. Studies of the helminth fauna of Norway XX: Seasonal cycles of fish parasites in the River Glomma. Norwegian Journal of Zoology 20: 9-18.

Halvorsen O, Andersen K. 1984. The ecological interaction between arctic charr, Salvelinus alpinus (L.), and the plerocercoid stage of Diphyllobotrium ditremum. Journal of Fish Biology 25: 305-316. doi: 10.1111/j.1095-8649.1984.tb04878.x

Hammar J. 2000. Cannibals and parasites: conflicting regulators of bimodality in high latitude Arctic char, Salvelinus alpinus. Oikos 88: 33-47. doi: 10.1034/j.1600-0706.2000.880105.x

Hanzelová V, Scholz T, Gerdeaux DK. 2002. A Comparative Study of Eubothrium salvelini and E. crassum (Cestoda: Pseudophyllidea) Parasites of Arctic Charr and Brown Trout in Alpine Lakes. Environmental Biology of Fishes 61: 245-256. doi: 10.1023/A:1016014505671

Hartig F. 2019. DHARMa: Residual Diagnostics for Hierarchical (MultiLevel/Mixed) Regression Models. R Package Version 0.2.4 ed.

Henricson J, Nyman L. 1976. The ecological and Genetical Segregation of Two Symaptric Species of Dwarfed Char (Salvelinus alpinus (L.)) species Complex). Drottingsholm. Report of the Institute of Freshwater Research Drottingsholm.

Henriksen EH, Frainer A, Knudsen R, Kristoffersen R, Kuris AM, Lafferty KD, Amundsen P-A. 2019. Fish culling reduces tapeworm burden in Arctic charr by increasing parasite mortality rather than by reducing density-dependent transmission. Journal of Applied Ecology 56: 1482-1491. doi: 10.1111/1365-2664.13369

Henriksen EH, Knudsen R, Kristoffersen R, Kuris AM, Lafferty KD, Siwertsson A, Amundsen P-A. 2016. Ontogenetic dynamics of infection with Diphyllobothrium spp. cestodes in sympatric Arctic charr Salvelinus alpinus (L.) and brown trout Salmo trutta L. Hydrobiologia 783: 37-46. doi: 10.1007/s10750-015-2589-2

Hernandez AD, Muzzall PM. 1998. Seasonal patterns in the biology of Eubothrium salvelini infecting brook trout in a creek in lower Michigan. Journal of Parasitology 84: 1119-1123. doi: 10.2307/3284659

Hoefs J. 2013. Stable isotope geochemistry. New York, NY, USA Springer Science \& Business Media. 286 p. doi: 10.1007/978-3-54070708-0

Hoffmann R, Kennedy CR, Meder J. 1986a. Effects of Eubothrium salvelini Schrank, 1790 on arctic charr, Salvelinus alpinus (L.), in an alpine lake. Journal of Fish Diseases 9: 153-157. doi: 10.1111/j.13652761.1986.tb00997.x

Hoffmann R, Meder J, Klein M, Osterkornj K, Negele RD. 1986b. Studies on lesions caused by plerocercoids of Triaenophorus nodulosus in some fish of an alpine lake, the Königssee. Journal of Fish Biology 28: 701-712. doi: 10.1111/j.1095-8649.1986.tb05204.x

Jacobsen L, Berg S, Baktoft H, Skov C. 2015. Behavioural strategy of large perch Perca fluviatilis varies between a mesotrophic and a hypereutrophic lake. Journal of Fish Biology 86: 1016 - 1029. doi: 10.1111/jfb.12613

Jensen KW. 1954. Fisk og fiske i Norsjø. Oslo. Direktoratet for vilt of Ferskvannsfisk - Fiskeforskningen, Zoologisk Museum, Universitetet i Oslo.

Kabata Z. 1969. Revision of the Genus Salmincola Wilson, 1915 (Copepoda: Lernaeopodidae). Journal of the Fisheries Research Board of Canada 26: 2987-3041. doi: 10.1139/f69-285
Karvonen A, Lundsgaard-Hansen B, Jokela J, Seehausen O. 2013. Differentiation in parasitism among ecotypes of whitefish segregating along depth gradients. Oikos 122: 122-128. doi: 10.1111/j.16000706.2012.20555.x

Karvonen A., Valtonen ET. 2004. Helminth assemblages of whitefish (Coregonus lavaretus) in interconnected lakes: similaryty as a function of species specific parasites and geographical separation. Journal of Parasitology 90: 471-476. doi: 10.1645/GE-3099

Kennedy C. 1978. The parasite fauna of resident char Salvelinus alpinus from Arctic island, with special reference to Bear Island. Journal of Fish Biology 13: 457-466. doi: 10.1111/j.1095-8649.1978.tb03455.x

Khan RA. 2012. Host-parasite interactions in some fish species. Journal of Parasitology Research 2012: 237-280. doi: 10.1155/2012/237280

Knudsen R, Amundsen P-A, Klemetsen A. 2003. Inter- and intramorph patterns in helminth communities of sympatric whitefish morphs. Journal of Fish Biology 62: 847-859. doi: 10.1046/j.10958649.2003.00069.x

Knudsen R, Amundsen P-A, Nilsen R, Kristoffersen R, Klemetsen A. 2008. Food borne parasites as indicators of trophic segregation between Arctic charr and brown trout. Environmental Biology of Fishes 83: 107-116. doi: 10.1007/s10641-007-9216-7

Knudsen R, Curtis MA, Kristoffersen R. 2004. Aggregation of helminths: the role of feeding behaviour of fish hosts. Journal of Parasitology 90 : 1-7. doi: 10.1645/GE-3184

Knudsen R, Kristoffersen R, Amundsen P-A. 1997. Parasite communities in two sympatric morphs of Arctic charr, Salvelinus alpinus (L.), in northern Norway Dwarf charr Normal charr. Canadian Journal of Zoology 75: 2003-2009. doi: 10.1139/z97-833

Knudsen R, Primicerio R, Amundsen P-A, Klemetsen A. 2009. Temporal stability of individual feeding specialization may promote speciation. The Journal of Animal Ecology 79: 161-168. doi: 10.1111/j.13652656.2009.01625.x

Knudsen R, Siwertsson A, Adams CE, Newton J, Amundsen P-A. 2014. Similar patterns of individual niche use are revealed by different timeintegrated trophic tracers (stable isotopes and parasites). Ecology of Freshwater Fish 23: 259-268. doi: 10.1111/eff.12074

Lien L. 1970. Studies of the helminth fauna of Norway XIV: Triaenophorus nodulosus (Pallas, 1960) (Cestoda) in Bogstad Lake II. Development and life span of the plerocercoids in perch (Perca fluviatilis L. 1758). Nytt Magasin for Zoologi 18: 85-96.

Locke SA, Marcogliese DJ, Valtonen ET. 2014. Vulnerability and diet breadth predict larval and adult parasite diversity in fish of the Bothnian Bay. Oecologia 174: 253-262. doi: 10.1007/s00442-0132757-X

Locke SA, Mclaughlin JD, Marcogliese DJ. 2013. Predicting the similarity of parasite communities in freshwater fishes using the phylogeny, ecology and proximity of hosts. Oikos 122: 73-83. doi: 10.1111/j.16000706.2012.20211.x

Luque JL, Poulin R. 2008. Linking ecology with parasite diversityin Neotropical fishes. Journal of Fish Biology 72: 189-204. doi: 10.1111/j.1095-8649.2007.01695.x

Lüdecke D. 2018. ggeffects: Tidy Data Frames of Marginal Effects from Regression Models. Journal of Open Source Software 3: 772. doi: 10.21105/joss.00772

Lyche Solheim A., Skotte G. 2016 ØKOSTOR: Basisovervåking av store innsjøer 2015. Utprøving av metodikk for overvåking og klassifisering av økologisk tilstand i henhold til vannforskriften. Miljødirektoratet rapport M-587, NIVA rapport 7070-2016, 151 p. https://www.miljodirektoratet.no/globalassets/publikasjoner/M587/ M587.pdf Accessed: 2020-05-20.

Marcogliese DJ. 1995. The role of zooplankton in the transmission of helminth parasites to fish. Reviews in Fish Biology and Fisheries 5: 336-371. doi: 10.1007/BF00043006

Mikheev VN, Pasternak AF, Valtonen ET, Lankinen Y. 2001. Spatial distribution and hatching of overwintered eggs in a fish ectoparasite Argulus coregoni Thorell (Crustacea: Branchiura). Diseases of Aquatic 
Organisms 46: 123-128. doi: 10.3354/dao046123

Minagawa M, Wada E. 1984. Stepwise enrichment of ${ }^{15} \mathrm{~N}$ along food chains: Further evidence and the relation between delta ${ }^{15} \mathrm{~N}$ and animal age. Geochimica et Cosmochimica Acta 48: 1135-1140. doi: 10.1016/0016-7037(84)90204-7

Olk TR, Karlsson T, Lydersen E, Økelsrud A. 2016. Seasonal Variations in the Use of Profundal Habitat among Freshwater Fishes in Lake Norsjø, Southern Norway, and Subsequent Effects on Fish Mercury Concentrations. Environments 3(4): 29. doi: 10.3390/ environments3040029

Paterson RA, Nefjodova J, Salis RK, Knudsen R. 2019. Exploring trophic niches and parasite communities of sympatric Arctic charr and brown trout populations of southern Norway. Hydrobiologia 840: 271-280. doi: 10.1007/s10750-019-3956-1

Peterson BJ, Fry B. 1987. Stable isotopes in ecosystem studies. Annual Review of Ecology, Evolution and Systematics 18: 293-320. doi: 10.1146/annurev.es.18.110187.001453

Post DM. 2002. Using stable isotopes to estimate trophic position: models, methods, and assumptions. Ecology 83: 703-718. doi: 10.1890/0012-9658(2002)083[0703:USITET]2.0.CO;2

Poulin R. 1995. Phylogeny, Ecology, and the Richness of Parasite Communities in Vertebrates. Ecological Society of America 65: 283-302. doi: $10.2307 / 2937061$

Poulin R. 1997. Species richness of parasite assemblages: evolution and patterns. Annual Review of Ecology, Evolution and Systematics 28: 341-358. doi: 10.1146/annurev.ecolsys.28.1.341

Poulin R. 2000. Variation in the intraspecific relationship between fish length and intensity of parasitic infection: biological and statistical causes. Journal of Fish Biology 56: 123-137. doi: 10.1111/j.10958649.2000.tb02090.x

Poulin R. 2004. Macroecological patterns of species richness in parasite assemblages. Basic and Applied Ecology 5: 423-434. doi: 10.1016/j. baae.2004.08.003

Poulin R. 2007. Are there general laws in parasite ecology? Parasitology 134: 763-776. doi: 10.1017/S0031182006002150

Poulin R, Curtis M, Rau M. 1992. Effects of Eubothrium salvelini (Cestoda) on the behavior of Cyclops vernalis (Copepoda) and its susceptibility to fish predators. Parasitology 105: 265-271. doi: 10.1017/ S0031182000074199

Poulin R, Curtis MA, Rau ME. 1990. Responses of the fish ectoparasite Salmincola edwardsii (Copepoda) to stimulation, and their implication for host-finding. Parasitology 100: 417-421. doi: 10.1017/ s0031182000078707

Poulin R, Curtis MA, Rau ME. 1991. Size, behaviour, and acquisition of ectoparasitic copepods by brook trout, Salvelinus fontinalis. Oikos 61: 169-174. doi: 10.2307/3545334

Poulin R, Leung TLF. 2011. Body size, trophic level, and the use of fish as transmission routes by parasites. Oecologia 166: 731-738. doi: 10.1007/ s00442-011-1906-3

Pulkkinen K, Valtonen ET, Niemi A, Poikola K. 1999. The influence of food competition and host specificity on the transmission of Triaenophorus crassus (Cestoda) and Cystidicola farionis (Nematoda) to Coregonus lavaretus and Coregonus albula (Pisces:Coregonidae) in Finland. International Journal for Parasitology 29: 1753-1763. doi: 10.1016/S0020-7519(99)00128-9

R Developer Core Team. 2019. R: A language and environment for statistical computing. Vienna, Austria. R Foundation for Statistical Computing.

Rosen R, Dick TA. 1984. Growth and migration of plerocercoids of Triaenophorus crassus Forel and pathology in experimentally infected whitefish, Coregonus clupeaformis (Nitchill). Canadian Journal of Zoology 62: 203-211. doi: 10.1139/z84-034

Sandlund OT, Gunnarsson K, Jónasson PM, Jonsson B, Lindem T, Magnússon KP, Malmquist HJ, Sigurjónsdóttir H, Skúlason S. 1992. The Arctic Charr Salvelinus alpinus in Thingvallavatn. Oikos 64: 305-351. doi: $10.2307 / 3545056$
Sandlund OT, Brabrand A, Gjelland KØ, Høitomt LE, Linløkken AN, Olstad K, Pettersen O, Rustadbakken A. 2016. Overvåking av fiskebestander I store innsjøer. Metodeutprøving og anbefalinger. Norsk Institutt for Naturforvaltning, Report 1274, 74 p. http://hdl. handle.net/11250/2415467 Accessed: 2020-05-22.

Scholz T. 1999. Life cycle of species of Proteocephalus, parasites of fishes in the Palearctic region: a review. Journal of Helminthology 73(1): 1-19.

Scholz T, Garcia HH, Kuchta R, Wicht B. 2009. Update on the human broad tapeworm (genus Diphyllobothrium), including clinical relevance. Clinical Microbiology Reviews 22: 146-160. doi: 10.1128/ CMR.00033-08

Scott ME, Smith G. 1994. Parasitic and Infectious Diseases: Epidemiology and Ecology. San Diego. Academic Press, Book Marketing Department. $398 \mathrm{p}$.

Shimura S. 1983. Seasonal occurrence, sex ratio and site preference of Argulus coregoni Thorell (Crustacea: Branichiura) parasitic on cultured freshwater salmonids in Japan. Parasitology 86: 537-552. doi: 10.1017/S0031182000050721

Siwertsson A, Refsnes B, Frainer A, Amundsen P-A, Knudsen R. 2016. Divergence and parallelism of parasite infections in Arctic charr morphs from deep and shallow lake habitats. Hydrobiologia 783: 131-143. doi: 10.1007/s10750-015-2563-z

Skorping A. 1977. Seasonal variations in population structure of Bunodera luciopercae in perch in a small Norwegian forest lake. Norwegian Journal of Zoology 24: 446.

Skorping A. 1981. Seasonal dynamics in abundance, development and pattern of infection of Bunodera luciopercae (Müller) in perch, Perca fluviatilis L. from an oligotrophic lake in Norway. Journal of Fish Biology 18: 401-410. doi: 10.1111/j.1095-8649.1981.tb03781.x

Smith HD. 1973. Observations on the Cestode Eubothrium salvelini in Juvenile Sockeye Salmon (Oncorhynchus nerka) at Babine Lake, British Columbia. Journal of the Fisheries Research Board of Canada 30: 947-964. doi: 10.1139/f73-156

Sterud E. 1999. Parasitter hos norske ferskvannsfisk. Oslo: Norsk Zoologisk Forening.

Timi JT, Lanfranchi AL. 2013. Ontogenetic changes in heterogeneity of parasite communities of fish: disentangling the relative role of compositional versus abundance variability. Parasitology 140: 309-317. doi: $10.1017 / \mathrm{S} 0031182012001606$

Timi JT, Luque JL, Poulin R. 2010. Host ontogeny and the temporal decay of similarity in parasite communities of marine fish. International Journal for Parasitology 40: 963-968. doi: 10.1016/j.ijpara.2010.02.005

Timi JT, Rossin MA, Alarcos AJ, Braicovich PE, Cantatore DMP, Lanfranchi AL. 2011. Fish trophic level and the similarity of larval parasite assemblages. International Journal for Parasitology 41: 309316. doi: 10.1016/j.ijpara.2010.10.002

Valtonen ET, Julkunen M. 1995. Influence of the transmission of parasites from prey fishes on the composition of the parasite community of a predatory fish. Canadian Journal of Fisheries and Aquatic Sciences 52: 233-245. doi: 10.1139/f95-531

Valtonen ET, Marcogliese DJ, Julkunen M. 2010. Vertebrate diets derived from trophically transmitted fish parasites in the Bothnian Bay. Oecologia 162: 139-152. doi: 10.1007/s00442-009-1451-5

Vander Zanden MJ, Rasmussen JB. 1999. Primary consumer delta ${ }^{13} \mathrm{C}$ and delta ${ }^{15} \mathrm{~N}$ and the trophic position of aquatic consumers. Ecology 80: 1395-1404. doi: 10.1890/0012-9658(1999)080[1395:PCCANA]2.0.CO;2

Vann-nett. 2019. Norsjø. https://vann-nett.no/portal/\#/waterbody/016-6-L Accessed: 2019-10-16.

Vik R. 1959. Studies of the helminth fauna of Norway III: Occurrence and distribution of Triaenophorus robustus Olsson, 1892 and T. nodulosus (Pallas, 1760) (Cestoda) in Norway. Nytt Magasin for Zoologi 8: 64-73.

Vik R. 1963. Studies of the helminth fauna of Norway. IV. Occurrence and distribution of Eubothrium crassum (Bloch, 1779) and E. salvelini (Schrank, 1790) (Cestoda) in Norway, with notes on their life cycles. Nytt Magasin for Zoologi 11: 47-73. 
Waeschenbach A, Brabec J, Scholz T, Littlewood DTJ, Kuchta R. 2017. The catholic taste of broad tapeworms - Multiple routes to human infection. International Journal for Parasitology 47: 831-843. doi: 10.1016/j.ijpara.2017.06.004

Wayland MT, Gibson DI, Sommerville C. 2004. Echinorhynchus salmonis Müller, 1784 (Acanthocephala: Echinorhynchidae) from the Bothnian Bay, Baltic Sea: morphological variability and radial assymetry of probosci hooks. Systematic Parasitology 58: 149-158. doi: 10.1023/B:S YPA.0000029419.07989.1a

Westrelin S, Roy R, Tissot-Rey L, Bergès L, Argillier C. 2018. Habitat use and preference of adult perch (Perca fluviatilis L.) in a deep reservoir: variations with seasons, water levels and individuals. Hydrobiologia 809: 121-139. doi: 10.1007/s10750-017-3454-2

Wickham H. 2016. ggplot2: Elegant Graphics for Data Analysis. New York. Springer-Verlag. VIII, 213 p. doi: 10.1007/978-0-387-98141-3

Wilson K, Grenfell BT. 1997. Generalized linear modelling for parasitologists. Parasitology Today 13: 33-38. doi: 10.1016/S01694758(96)40009-6

Woo PTK. 2006. Protozoan and Metazoan infections. Wallingford, UK. CAB International. $800 \mathrm{p}$.

Zamora L, Moreno-Amich R. 2002. Quantifying the activity and movement of perch in a temperate lake by integrating acoustic telemetry and a geographic information system. Hydrobiologia 483: 209-218. doi: 10.1023/A:1021396016424

Editorial responsibility: Jan Grimsrud Davidsen.

This article is open-access and distributed under the terms of the Creative Commons Attribution 4.0 International license. This permits all noncommercial use, distribution, and reproduction in any medium, provided the original work is properly cited.

(http://creativecommons.org/licenses/by/4.0/). 
Appendix I. Model selection.

The base model Argulus coregoni in whitefish was selected according to the lowest AIC. Candidate models are presented in Table A1-1. The model including season as explanatory variable was considered the model with the best fit.

Table Al-I. Candidate models for the base model for Argulus coregoni in Whitefish.

\begin{tabular}{ll}
\hline Explanatory variable & AIC \\
\hline Length & 75.05866 \\
Weight & 75.81601 \\
\hline Age & 80.14130 \\
\hline$\delta^{13} \mathrm{C}$ & 72.40155 \\
$\delta^{15} \mathrm{~N}$ & 79.48613 \\
Sex & 80.79960 \\
Location & 79.59549 \\
Season & 65.92807 \\
C/N-ratio & 79.15692 \\
\hline
\end{tabular}

Subsequently, length, weight, $\delta^{13} \mathrm{C}, \delta^{15} \mathrm{~N}$, sex, age, location, and the $\mathrm{C} / \mathrm{N}$-ratio were added in separate models to the base model containing season. These models, which are nested in the base model were compared to the base mode using maximum likelihood. Comparisons to the base model are presented in Table A1-2.

Table Al-2. Advanced models and the results of the comparison to the base model by maximum likelihood.

\begin{tabular}{lll}
\hline Base Model & Explanatory variable & $\mathrm{p}$ \\
\hline Season & Length & $>0.10$ \\
Season & Weight & $>0.10$ \\
Season & $\delta^{13} \mathrm{C}$ & $>0.05$ \\
Season & $\delta^{15} \mathrm{~N}$ & $>0.10$ \\
Season & Sex & $>0.10$ \\
Season & Age & $>0.10$ \\
Season & Location & $>0.10$ \\
Season & C/N-ratio & $>0.05$ \\
\hline
\end{tabular}

As no more advanced model was significantly better than the base model, the base model only containing season as explanatory variable was chosen as the final model.

The AICs for different base models for the number of Salmincola sp. in whitefish is shown in Table A1-3.

Table Al-3. AIC table for the model selection of the base model for Salmincola sp. in whitefish.

\begin{tabular}{ll}
\hline Explanatory variable & AIC \\
\hline Length & 48.44164 \\
Weight & 48.43219 \\
\hline Age & 48.44905 \\
$\delta^{13} \mathrm{C}$ & 48.44557 \\
$\delta^{15} \mathrm{~N}$ & 48.30059 \\
Sex & 48.10730 \\
\hline Location & 48.40397 \\
Season & 47.49582 \\
\hline C/N-ratio & 48.00397 \\
\hline
\end{tabular}

The model including season as explanatory variable performed best. However, its performance was similar to all the other models. The model including season was advanced, and results of maximum likelihood tests of the more advanced models are presented in Table A1-4. None of the more advanced models was significantly better than the base model, and the base model was thus selected.

Table Al-4. Comparison of more advanced models to the base model of Salmincola sp. in whitefish by maximum likelihood.

\begin{tabular}{lll}
\hline Base Model & Explanatory variable & $\mathrm{p}$ \\
\hline Season & Length & $>0.10$ \\
Season & Weight & $>0.10$ \\
Season & $\delta^{13} \mathrm{C}$ & $>0.10$ \\
Season & $\delta^{15} \mathrm{~N}$ & $>0.10$ \\
Season & Sex & $>0.10$ \\
Season & Age & $>0.10$ \\
Season & Location & $>0.10$ \\
Season & C/N-ratio & $>0.10$ \\
\hline
\end{tabular}

The base model selection for the number of Proteocephalus sp. in whitefish is presented in Table A1-5. Four of the candidate models could not be calculated. Length was included in the base model.

Table Al-5. AIC table for base model selection for Proteocephalus sp. in whitefish.

\begin{tabular}{ll}
\hline Explanatory variable & AIC \\
\hline Length & 94.37454 \\
Weight & 97.29397 \\
\hline Age & 96.21320 \\
$\delta^{13} \mathrm{C}$ & NA \\
$\delta^{15} \mathrm{~N}$ & NA \\
Sex & 97.30856 \\
Location & NA \\
Season & NA \\
C/N-ratio & 101.38057 \\
\hline
\end{tabular}

The comparison to more advanced models is shown in Table A1-6. The model including length and season was the only model significantly better than the base model. This model was initially selected. However, the model was not viable according to curved patterns in the residuals.

Table Al-6. Model comparison of more advanced models for Proteocephalus sp. in whitefish to the base model by maximum likelihood.

\begin{tabular}{lll}
\hline Base Model & Explanatory variable & $\mathrm{p}$ \\
\hline Length & Sex & $>0.10$ \\
Length & Location & $>0.10$ \\
Length & Season & $<0.05$ \\
Length & Weight & $>0.05$ \\
Length & Age & $>0.10$ \\
Length & $\delta^{13} \mathrm{C}$ & $>0.10$ \\
Length & $\delta^{15} \mathrm{~N}$ & $>0.10$ \\
\hline
\end{tabular}


Appendix I continued.

Adding quadratic terms to the model for the number of Proteocephalus sp. in whitefish was attempted. New base models were created containing quadratic terms of the numerical variables. An AIC table for their comparison is presented in Table A1-7.

Table Al-7. AIC table for the selection of the quadratic base model for Proteocephalus sp. in whitefish.

\begin{tabular}{ll}
\hline Explanatory variable & AIC \\
\hline Length (quadratic) & 93.09508 \\
Weight (quadratic) & 96.15357 \\
\hline Age (quadratic) & 91.78830 \\
$\delta^{13} \mathrm{C}$ (quadratic) & 102.95684 \\
$\delta^{15} \mathrm{~N}$ (quadratic) & 103.79494 \\
$\mathrm{C} / \mathrm{N}-$ ratio (quadratic) & 97.30856 \\
Sex & 102.44419 \\
Location & 100.89044 \\
Season & 103.33786 \\
\hline
\end{tabular}

The base model containing the quadratic term of age was selected, and more advanced models adding the other variables one by one were created. The comparison of the more advanced models to the base model by maximum likelihood is shown in Table A1-8. None of the more advanced models were significantly better than the base model, and the base model containing the quadratic term for age was selected. The residuals for this models did not exhibit curved patterns.

Table Al-8. Results of the comparison of more advanced models to the quadratic base model for Proteocephalus sp. in whitefish by maximum likelihood.

\begin{tabular}{lll}
\hline Base Model & Explanatory variable & $\mathrm{p}$ \\
\hline Age (quadratic) & Length & $>0.10$ \\
Age (quadratic) & Weight & $>0.10$ \\
Age (quadratic) & $\delta^{13} \mathrm{C}$ & $>0.10$ \\
Age (quadratic) & $\delta^{15} \mathrm{~N}$ & $>0.10$ \\
Age (quadratic) & $\mathrm{C} / \mathrm{N}-$ ratio & $>0.10$ \\
Age (quadratic) & Sex & $>0.05$ \\
Age (quadratic) & Location & $>0.10$ \\
Age (quadratic) & Season & $>0.10$ \\
\hline
\end{tabular}

Different base models for acanthocephalans in whitefish are compared according to the AIC in Table A1-9. The model including age as explanatory variable was selected. It performed similarly to the model containing length.
Table Al-9. AIC table for base models of the number of acanthocephalans in whitefish.

\begin{tabular}{ll}
\hline Explanatory variable & AIC \\
\hline Length & 172.6141 \\
\hline Weight & 176.6409 \\
\hline Age & 172.4202 \\
\hline$\delta^{13} \mathrm{C}$ & 179.1248 \\
$\delta^{15} \mathrm{~N}$ & 182.3797 \\
$\mathrm{C} / \mathrm{N}$-ratio & 176.6081 \\
Sex & 179.3307 \\
Location & 183.4828 \\
Season & 177.8922 \\
\hline
\end{tabular}

The base model was compared to more advanced models using maximum likelihood (Table A1-10). Both advanced models containing season and the $\mathrm{C} / \mathrm{N}$-ratio were significantly better than the base model. The advanced models performing better than the base model were compared by AIC (Table A1-11), and the model containing age and season as explanatory variables was selected. However, as the residuals exhibited curved patterns, the inclusion of quadratic terms in a new base model was attempted.

Table Al-10. Model comparisons for acanthocephalans in whitefish to the base model only containing age as explanatory variable by maximum likelihood.

\begin{tabular}{lll}
\hline Base Model & Explanatory variable & $\mathrm{p}$ \\
\hline Age & Length & $>0.05$ \\
Age & Weight & $>0.10$ \\
Age & $\delta^{13} \mathrm{C}$ & $>0.05$ \\
Age & $\delta^{15} \mathrm{~N}$ & $>0.10$ \\
Age & Sex & $>0.10$ \\
Age & Season & $<0.01$ \\
Age & Location & $>0.10$ \\
Age & C/N-ratio & $<0.05$ \\
\hline
\end{tabular}

Table Al-II. AIC table for model comparison of more advanced models for acanthocephalans in whitefish and the base mode using AIC.

\begin{tabular}{ll}
\hline Explanatory variable & AIC \\
\hline Age & 172.4202 \\
Age + Season & 166.4647 \\
Age + C/N-ratio & 168.3035 \\
\hline
\end{tabular}

The model containing a quadratic term of age as explanatory variable performed best according to the AIC (Table A1-12). According to maximum likelihood tests, more advanced models containing Season and the $\mathrm{C} / \mathrm{N}$-ratio performed better than the base model (Table A1-13). These models were compared using the AIC (Table A1-14), and the model containing a quadratic term for age and season was performing best. However, the residuals of both more advanced models exhibited curved patterns, and the base model was selected based on the best residual fit. 
Appendix I continued.

Table AI-I2. AIC table for the comparison of quadratic models for the number of acanthocephalans in whitefish.

\begin{tabular}{ll}
\hline Explanatory variable & AIC \\
\hline Length (quadratic) & 171.0887 \\
\hline Weight (quadratic) & 172.1426 \\
\hline Age (quadratic) & 170.6091 \\
$\delta^{13} \mathrm{C}$ (quadratic) & 177.0976 \\
$\delta^{15} \mathrm{~N}$ (quadratic) & 184.2953 \\
$\mathrm{C} / \mathrm{N}$-ratio (quadratic) & 178.6064 \\
Sex & 179.3307 \\
Location & 183.4828 \\
Season & 177.8922 \\
\hline
\end{tabular}

Table AI-I3. Tests between the quadratic base model for acanthocephalans in whitefish to more advanced models using maximum likelihood.

\begin{tabular}{lll}
\hline Base Model & Explanatory variable & $\mathrm{p}$ \\
\hline Age (quadratic) & Length & $>0.10$ \\
Age (quadratic) & Weight & $>0.10$ \\
Age (quadratic) & $\delta^{13} \mathrm{C}$ & $>0.10$ \\
Age (quadratic) & $\delta^{15} \mathrm{~N}$ & $>0.10$ \\
Age (quadratic) & $\mathrm{C} / \mathrm{N}$-ratio & $<0.05$ \\
Age (quadratic) & Sex & $>0.10$ \\
Age (quadratic) & Location & $<0.05$ \\
Age (quadratic) & Season & $>0.10$ \\
\hline
\end{tabular}

Table Al-14. Comparison of more advanced quadratic models for the abundance of acanthocephalans in whitefish using AIC.

\begin{tabular}{ll}
\hline Explanatory variable & AIC \\
\hline Age (quadratic) & 170.6091 \\
Age (quadratic) + Season & 166.2518 \\
Age (quadratic) + C/N-ratio & 167.6942 \\
\hline
\end{tabular}

For the number of copepod transmitted parasites in whitefish, the base model containing length as explanatory variable had the lowest AIC (Table A1-15). The model containing season as aditional explanatory variable was the only higher performing more advanced model according to maximum likelihood (Table A1-16). However, as this model showed curved patterns in its residual distribution, new base models were created using quadratic terms.

Table Al-I5. AIC table for base models of copepod transmitted parasites in whitefish.

\begin{tabular}{ll}
\hline Explanatory variable & AIC \\
\hline Length & 101.5716 \\
Weight & 104.8061 \\
\hline Age & 102.7190 \\
$\delta^{13} \mathrm{C}$ & 109.1295 \\
$\delta^{15} \mathrm{~N}$ & 109.5603 \\
$\mathrm{C} / \mathrm{N}$-ratio & 108.9059 \\
Sex & 105.1300 \\
Location & 110.5478 \\
Season & 108.5875 \\
\hline
\end{tabular}

Table Al-16. Comparison of more advanced models to the base model of copepod transmitted parasites in whitefish by maximum likelihood.

\begin{tabular}{lll}
\hline Base Model & Explanatory variable & $\mathrm{p}$ \\
\hline Length & Weight & $>0.05$ \\
Length & Age & $>0.10$ \\
Length & $\delta^{13} \mathrm{C}$ & $>0.10$ \\
Length & $\delta^{15} \mathrm{~N}$ & $>0.10$ \\
Length & Sex & $>0.10$ \\
Length & Season & $<0.05$ \\
Length & Location & $>0.10$ \\
Length & C/N-ratio & $>0.10$ \\
\hline
\end{tabular}

The base model for copepod transmitted parasites containing the quadratic term for age was the best model according to the AIC (Table A1-17). None of the more advanced models were significantly better than the base model according to maximum likelihood (Table A1-18). Consequently, the base model was selected.

Table AI-17. AIC table for quadratic base models for copepod transmitted parasites in whitefish.

\begin{tabular}{ll}
\hline Explanatory variable & AIC \\
\hline Length (quadratic) & 99.61478 \\
\hline Weight (quadratic) & 103.14450 \\
Age (quadratic) & 97.50996 \\
$\delta^{13} \mathrm{C}$ (quadratic) & 110.39990 \\
$\delta^{15} \mathrm{~N}$ (quadratic) & 111.55580 \\
$\mathrm{C} / \mathrm{N}$-ratio (quadratic) & 110.86819 \\
Sex & 105.12996 \\
Location & 110.54780 \\
\hline Season & 108.58752 \\
\hline
\end{tabular}

Table Al-18. Comparison of more advanced models to the quadratic base model for copepod transmitted parasites in whitefish using maximum likelihood.

\begin{tabular}{lll}
\hline Base Model & Explanatory variable & $\mathrm{p}$ \\
\hline Age (quadratic) & Length & $>0.10$ \\
Age (quadratic) & Weight & $>0.10$ \\
Age (quadratic) & $\delta^{13} \mathrm{C}$ & $>0.10$ \\
Age (quadratic) & $\delta^{15} \mathrm{~N}$ & $>0.10$ \\
Age (quadratic) & $\mathrm{C} / \mathrm{N}-$ ratio & $>0.10$ \\
Age (quadratic) & Sex & $>0.10$ \\
Age (quadratic) & Location & $>0.05$ \\
Age (quadratic) & Season & $>0.10$ \\
\hline
\end{tabular}

The base model for Salmincola edwadsii in charr using age as explanatory variable had the lowest AIC (Table A1-19). However, it performed similarly to models containing length and $\delta^{13} \mathrm{C}$. None of the more advanced models was significantly better than the base model according to maximum likelihood (Table A1-20). Consequently, the base model including age was selected. 
Appendix I continued.

Table A1-19. AIC table for base models of the number of Salmincola edwardsii in charr.

\begin{tabular}{ll}
\hline Explanatory variable & AIC \\
\hline Length & 78.68604 \\
Weight & NA \\
\hline Age & 78.30467 \\
\hline$\delta^{13} \mathrm{C}$ & 78.87065 \\
$\delta^{15} \mathrm{~N}$ & NA \\
C/N-ratio & NA \\
Sex & NA \\
Season & 80.84004 \\
Location & NA \\
\hline
\end{tabular}

Table A1-20. Model comparison of more advanced models for Salmincola edwardsii in charr to the base model containing age by maximum likelihood.

\begin{tabular}{lll}
\hline Base Model & Explanatory variable & $\mathrm{p}$ \\
\hline Age & Length & $>0.10$ \\
Age & Weight & $>0.10$ \\
Age & $\delta^{13} \mathrm{C}$ & $\mathrm{NA}$ \\
Age & $\delta^{15} \mathrm{~N}$ & $>0.10$ \\
Age & Sex & $\mathrm{NA}$ \\
Age & Location & $>0.10$ \\
Age & Season & $\mathrm{NA}$ \\
Age & C/N-ratio & $\mathrm{NA}$ \\
\hline
\end{tabular}

The base model for cysts in charr with the lowest AIC used age as explanatory variable (Table A1-21). More advanced models containing length and weight were both significantly better than the base model according to maximum likelihood (Table A1-22). Comparing the more advanced models to the base model by AIC revealed, that the model containing age and length was the best model (Table A1-23). However, as age and length exhibited colinearity, and age was not significant in this model, the base model was selected.

Table A1-21 base model comparison for the number of cysts in charr using AIC.

\begin{tabular}{ll}
\hline Explanatory variable & AIC \\
\hline Length & 598.4953 \\
Weight & 598.6042 \\
\hline Age & 592.5246 \\
$\delta^{13} \mathrm{C}$ & 609.3290 \\
$\delta^{15} \mathrm{~N}$ & 608.9781 \\
$\mathrm{C} / \mathrm{N}$-ratio & 609.4156 \\
Sex & 609.7253 \\
Season & 610.8502 \\
Location & 609.5858 \\
\hline
\end{tabular}

Table A1-22. Comparing more advanced models to the base model for cysts in charr using maximum likelihood.

\begin{tabular}{lll}
\hline Base Model & Explanatory variable & $\mathrm{p}$ \\
\hline Age & Length & $<0.01$ \\
Age & Weight & $<0.05$ \\
Age & $\delta^{13} \mathrm{C}$ & $>0.10$ \\
Age & $\delta^{15} \mathrm{~N}$ & $>0.05$ \\
Age & $\mathrm{C} / \mathrm{N}-$ ratio & $>0.10$ \\
Age & Sex & $>0.10$ \\
Age & Season & $>0.10$ \\
Age & Location & $>0.10$ \\
\hline
\end{tabular}

Table Al-23. AIC table for more advanced models and base model for cysts in charr.

\begin{tabular}{ll}
\hline Explanatory variable & AIC \\
\hline Age & 592.5246 \\
Age + Length & 587.1827 \\
Age + Weight & 590.5388 \\
\hline
\end{tabular}

The selected base model for the number of Eubothrium salvelini in charr with age as explanatory variable had the lowest AIC (Table A1-24). Only the more advanced model containing age and season was significantly better according to maximum likelyhood (Table A1-25). Consequently, the model containing age and season was selected.

Table Al-24. AIC table comparing base models for Eubothrium salvelini in charr.

\begin{tabular}{ll}
\hline Explanatory variable & AIC \\
\hline Length & 306.2600 \\
Weight & 300.6607 \\
Age & 295.8292 \\
$\delta^{13} \mathrm{C}$ & 313.4788 \\
$\delta^{15} \mathrm{~N}$ & 311.8414 \\
$\mathrm{C} / \mathrm{N}-$ ratio & 316.9909 \\
Sex & 314.4400 \\
Season & 304.0997 \\
Location & 315.0706 \\
\hline
\end{tabular}

Table Al-25. Comparison of more advanced models for Eubothrium salvelini in charr to the base model containing age by maximum likelyhood.

\begin{tabular}{lll}
\hline Base Model & Explanatory variable & $\mathrm{p}$ \\
\hline Age & Length & $>0.10$ \\
Age & Weight & $>0.10$ \\
Age & $\delta^{13} \mathrm{C}$ & $>0.10$ \\
Age & $\delta^{15} \mathrm{~N}$ & $>0.10$ \\
Age & $\mathrm{C} / \mathrm{N}-$ ratio & $>0.10$ \\
Age & Sex & $>0.10$ \\
Age & Season & $<0.05$ \\
Age & Location & $>0.05$ \\
\hline
\end{tabular}


Appendix I continued.

The base model containing age was the best model for the abundance of Triaenophorus nodulosus in charr according to the AIC (Table A1-26). No additional variable seemed to improve the model according to comparisons to the base model by maximum likelihood (Table A1-27). The base model was selected.

Table Al-26. AIC table for base models of Triaenophorus nodulosus in charr.

\begin{tabular}{ll}
\hline Explanatory variable & AIC \\
\hline Length & 168.8717 \\
Weight & 169.0970 \\
\hline Age & 164.1332 \\
$\delta^{13} \mathrm{C}$ & 166.9320 \\
$\delta^{15} \mathrm{~N}$ & 168.1660 \\
$\mathrm{C} / \mathrm{N}-$ ratio & 168.4137 \\
Sex & 167.7276 \\
Season & 167.4710 \\
\hline Location & 165.5015 \\
\hline
\end{tabular}

Table Al-27. Comparison of more advanced models to the base model of Triaenophorus nodulosus in charr using maximum likelihood.

\begin{tabular}{lll}
\hline Base Model & Explanatory variable & $\mathrm{p}$ \\
\hline Age & Length & $>0.10$ \\
Age & Weight & $>0.10$ \\
Age & $\delta^{13} \mathrm{C}$ & $>0.10$ \\
Age & $\delta^{15} \mathrm{~N}$ & $>0.10$ \\
Age & $\mathrm{C} / \mathrm{N}$-ratio & $>0.10$ \\
Age & Sex & $>0.10$ \\
Age & Season & $>0.10$ \\
Age & Location & $>0.10$ \\
\hline
\end{tabular}

The best base model for Dibothriocephalus ditremus in charr contained sex as explanatory variable according to the AIC (Table A1-28). The addition of one extra explanatory variable did not improve this model according to maximum likelihood (Table A1-29). Consequently, the model only containing sex as explanatory variable was selected.

Table Al-28. AIC table for base models for Dibothriocephalus ditremus in charr.

\begin{tabular}{ll}
\hline Explanatory variable & AIC \\
\hline Length & 206.6559 \\
Weight & 207.7512 \\
\hline Age & 206.4372 \\
$\delta^{13} \mathrm{C}$ & 207.9316 \\
$\delta^{15} \mathrm{~N}$ & 207.8016 \\
\hline $\mathrm{C} / \mathrm{N}-$ ratio & 207.2861 \\
Sex & 204.0079 \\
Season & 208.4528 \\
\hline Location & 207.0390 \\
\hline
\end{tabular}

Table Al-29. Comparison of more advanced models to base model for Dibothriocephalus ditremus in charr according to maximum likelihood.

\begin{tabular}{lll}
\hline Base Model & Explanatory variable & $\mathrm{p}$ \\
\hline Sex & Length & $>0.10$ \\
Sex & Weight & $>0.10$ \\
Sex & $\delta^{13} \mathrm{C}$ & $>0.10$ \\
Sex & $\delta^{15} \mathrm{~N}$ & $>0.10$ \\
Sex & $\mathrm{C} / \mathrm{N}$-ratio & $>0.10$ \\
Sex & Age & $>0.10$ \\
Sex & Season & $>0.10$ \\
Sex & Location & $>0.10$ \\
\hline
\end{tabular}

The abundance of Dibothriocephalus dendriticus in charr was best explained by season according to the AIC (Table A1-30). Extending this model with either season or sex did not improve the model according to maximum likelihood (Table A1-31). None of the other variables produced viable models. The base mode using season as explanatory variable was selected.

Table Al-30. Base model comparison for Dibothriocephalus dendriticus in charr using AIC.

\begin{tabular}{ll}
\hline Explanatory variable & AIC \\
\hline Length & 107.9485 \\
Weight & 108.1215 \\
Age & NA \\
$\delta^{13} \mathrm{C}$ & 106.5658 \\
$\delta^{15} \mathrm{~N}$ & $\mathrm{NA}$ \\
$\mathrm{C} / \mathrm{N}-$ ratio & 108.0964 \\
Sex & $\mathrm{NA}$ \\
Season & 102.6733 \\
Location & 108.0871 \\
\hline
\end{tabular}

Table Al-3I. Model extension for Dibothriocephalus dendriticus in charr by maximum likelihood.

\begin{tabular}{lll}
\hline Base Model & Explanatory variable & $\mathrm{p}$ \\
\hline Season & Length & $\mathrm{NA}$ \\
Season & Weight & $\mathrm{NA}$ \\
Season & $\delta^{13} \mathrm{C}$ & $\mathrm{NA}$ \\
Season & $\delta^{15} \mathrm{~N}$ & $\mathrm{NA}$ \\
Season & $\mathrm{C} / \mathrm{N}-$ ratio & $\mathrm{NA}$ \\
Season & Age & $>0.10$ \\
Season & Sex & $>0.10$ \\
Season & Location & NA \\
\hline
\end{tabular}

The abundance of plerocercoid larvae of cestodes in charr was best predicted by age in the base model (Table A1-32). More advanced models containing length and weight as additional explanatory variables were significantly better than the base model according to maximum likelihood (Table A1-33). The model containing age and length was the best of these models according to the AIC (Table A1-34), and was consequently selected. 
Appendix I continued.

Table Al-32. AIC table for base models for plerocercoid larvae of cestodes in charr.

\begin{tabular}{ll}
\hline Explanatory variable & AIC \\
\hline Length & 607.4484 \\
Weight & 608.2406 \\
\hline Age & 602.2455 \\
$\delta^{13} \mathrm{C}$ & 619.7730 \\
$\delta^{15} \mathrm{~N}$ & 619.8596 \\
$\mathrm{C} / \mathrm{N}$-ratio & 620.1091 \\
Sex & 620.0495 \\
Season & 621.2955 \\
Location & 620.2163 \\
\hline
\end{tabular}

Table Al-33. Model comparisom using maximum likelihood between the base model for plerocercoid larvae of cestodes in charr and more advanced models.

\begin{tabular}{lll}
\hline Base Model & Explanatory variable & $\mathrm{p}$ \\
\hline Age & Length & $<0.01$ \\
Age & Weight & $<0.05$ \\
Age & $\delta^{13} \mathrm{C}$ & $>0.10$ \\
Age & $\delta^{15} \mathrm{~N}$ & $>0.05$ \\
Age & $\mathrm{C} / \mathrm{N}$-ratio & $>0.10$ \\
Age & Season & $>0.10$ \\
Age & Sex & $>0.10$ \\
Age & Location & $>0.10$ \\
\hline
\end{tabular}

Table Al-34. AIC table of advanced models for plerocercoid larvae of cestodes in charr and the base model containing age.

\begin{tabular}{ll}
\hline Explanatory variable & AIC \\
\hline Age & 602.2455 \\
Age + Length & 596.2323 \\
Age + Weight & 600.3266 \\
\hline
\end{tabular}

Age was the best single predictor of the abundance of copepod transmitted parasites in charr according to the AIC (Table A1-35). More advanced models additionally including length and weight were significantly better according to maximum likelihood (Table A1-36). Of these three models, the model containing age and length had the lowest AIC (Table A1-37), and was selected.

Table Al-35. AIC table for base models for the abundance of copepod transmitted parasites in charr.

\begin{tabular}{ll}
\hline Explanatory variable & AIC \\
\hline Length & 623.5514 \\
Weight & 623.4335 \\
\hline Age & 617.9401 \\
$\delta^{13} \mathrm{C}$ & 636.9653 \\
$\delta^{15} \mathrm{~N}$ & 638.1782 \\
$\mathrm{C} / \mathrm{N}$-ratio & 638.0415 \\
Sex & 637.2904 \\
Season & 637.6381 \\
\hline Location & 638.3867 \\
\hline
\end{tabular}

Table Al-36. Model comparison for advancing the model for copepod transmitted parasites in charr according to maximum likelihood.

\begin{tabular}{lll}
\hline Base Model & Explanatory variable & $\mathrm{p}$ \\
\hline Age & Length & $<0.01$ \\
Age & Weight & $<0.05$ \\
Age & $\delta^{13} \mathrm{C}$ & $>0.10$ \\
Age & $\delta^{15} \mathrm{~N}$ & $>0.10$ \\
Age & $\mathrm{C} / \mathrm{N}$-ratio & $>0.10$ \\
Age & Season & $>0.10$ \\
Age & Sex & $>0.10$ \\
Age & Location & $>0.10$ \\
\hline
\end{tabular}

Table Al-37. AIC table for base model and advanced models that were significantly better, modelling the abundance of copepod transmitted parasites in charr.

\begin{tabular}{ll}
\hline Explanatory variable & AIC \\
Age & 617.9401 \\
Age + Length & 612.8513 \\
Age + Weight & 615.5954 \\
\hline
\end{tabular}

The base model containing season had the lowest AIC for models of the abundance of acanthocephalans in perch (Table A1-38). The model containing both season and $\delta^{15} \mathrm{~N}$ was the only model significantly better than the base model (Table A1-39). The more advanced model was selected.

Table Al-38. AIC table for base models for the abundance of acanthocephalans in perch.

\begin{tabular}{ll}
\hline Explanatory variable & AIC \\
\hline Length & 393.9637 \\
Weight & 397.0874 \\
\hline Age & 397.0297 \\
$\delta^{13} \mathrm{C}$ & 397.3429 \\
$\delta^{15} \mathrm{~N}$ & 392.4103 \\
$\mathrm{C} / \mathrm{N}-$ ratio & 397.1748 \\
Sex & 393.8278 \\
Season & 384.4378 \\
\hline Location & 399.0303 \\
\hline
\end{tabular}

Table Al-39. Comparison of base model for acanthocephalans in perch to more advanced models using maximum likelihood.

\begin{tabular}{lll}
\hline Base Model & Explanatory variable & $\mathrm{p}$ \\
\hline Season & Length & $>0.05$ \\
Season & Weight & $>0.10$ \\
Season & $\delta^{13} \mathrm{C}$ & $>0.10$ \\
Season & $\delta^{15} \mathrm{~N}$ & $<0.05$ \\
Season & Sex & $>0.10$ \\
Season & Location & $>0.10$ \\
Season & Season & $>0.10$ \\
Season & C/N-ratio & $>0.10$ \\
\hline
\end{tabular}


Appendix I continued.

Age was the best predictor for copepod transmitted parasites in perch according to AIC (Table A1-40). According to maximum likelihood, the addition of season improved this model (Table A1-41). However, the model containing age and season as explanatory variables exhibited curved patterns in the residuals, and did not fit trends in the data well. The creation of quadratic models was attempted.

Table Al-40. AIC table for base models of copepod transmitted parasites in perch.

\begin{tabular}{ll}
\hline Explanatory variable & AIC \\
\hline Length & 74.14675 \\
Weight & 71.90901 \\
Age & 65.70433 \\
$\delta^{13} \mathrm{C}$ & 77.29767 \\
$\delta^{15} \mathrm{~N}$ & 75.53130 \\
$\mathrm{C} / \mathrm{N}-$ ratio & 77.26851 \\
Sex & 74.03819 \\
Season & 70.86179 \\
Location & 70.55145 \\
\hline
\end{tabular}

Table Al-4l. Model extension for copepod transmitted parasites in perch using maximum likelihood.

\begin{tabular}{lll}
\hline Base Model & Explanatory variable & $\mathrm{p}$ \\
\hline Age & Length & $>0.10$ \\
Age & Weight & $>0.10$ \\
Age & $\delta^{13} \mathrm{C}$ & $>0.10$ \\
Age & $\delta^{15} \mathrm{~N}$ & $>0.10$ \\
Age & Sex & $>0.10$ \\
Age & Location & $\mathrm{NA}$ \\
Age & Season & $<0.05$ \\
Age & C/N-ratio & $\mathrm{NA}$ \\
\hline
\end{tabular}

The model including age as quadratic term for the abundance of copepod transmitted parasites in perch was the best model according to AIC (Table A1-42). No additional term improved this model according to maximum likelihood (Table A1-43), and the quadratic base model was selected.

Table Al-42. AIC table for quadratic base models for the abundance of copepod transmitted parasites in perch.

\begin{tabular}{ll}
\hline Explanatory variable & $\mathrm{AIC}$ \\
\hline Length (quadratic) & 76.03101 \\
\hline Weight (quadratic) & 72.77307 \\
\hline Age (quadratic) & 67.18371 \\
\hline$\delta^{13} \mathrm{C}$ (quadratic) & 75.17302 \\
$\delta^{15} \mathrm{~N}$ (quadratic) & 77.24605 \\
$\mathrm{C} / \mathrm{N}$-ratio (quadratic) & 79.02974 \\
Sex & 74.03819 \\
Season & 70.86179 \\
Location & 70.55145 \\
\hline
\end{tabular}

Table Al-43. Model comparisons of more advanced models to the quadratic base model for the abundance of copepod transmitted parasites in perch.

\begin{tabular}{lll}
\hline Base Model & Explanatory variable & $\mathrm{p}$ \\
\hline Age (quadratic) & Length & $>0.10$ \\
Age (quadratic) & Weight & $>0.10$ \\
Age (quadratic) & $\delta^{13} \mathrm{C}$ & $>0.10$ \\
Age (quadratic) & $\delta^{15} \mathrm{~N}$ & $>0.10$ \\
Age (quadratic) & Sex & $>0.10$ \\
Age (quadratic) & Location & $>0.10$ \\
Age (quadratic) & Season & $\mathrm{NA}$ \\
Age (quadratic) & C/N-ratio & $>0.10$ \\
\hline
\end{tabular}


Appendix 2. Age and length distribution.

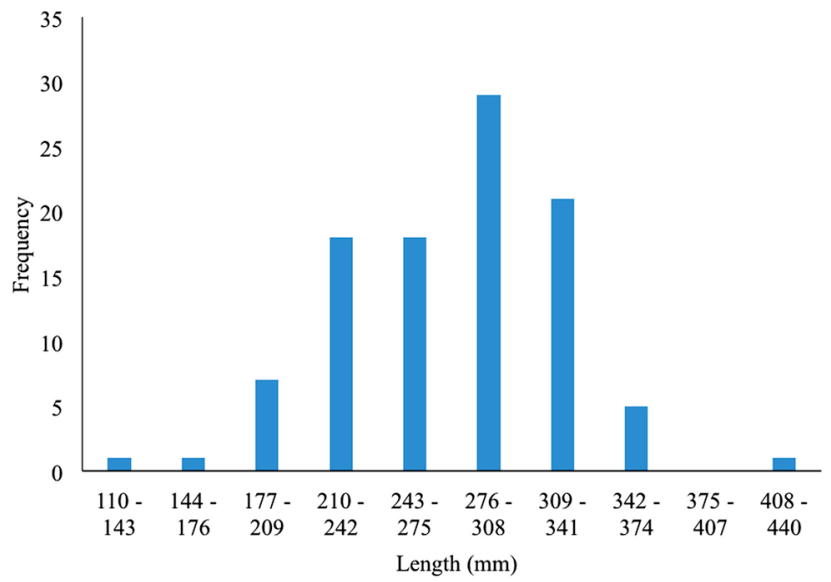

Figure A2-I. Length distribution of whitefish caught.

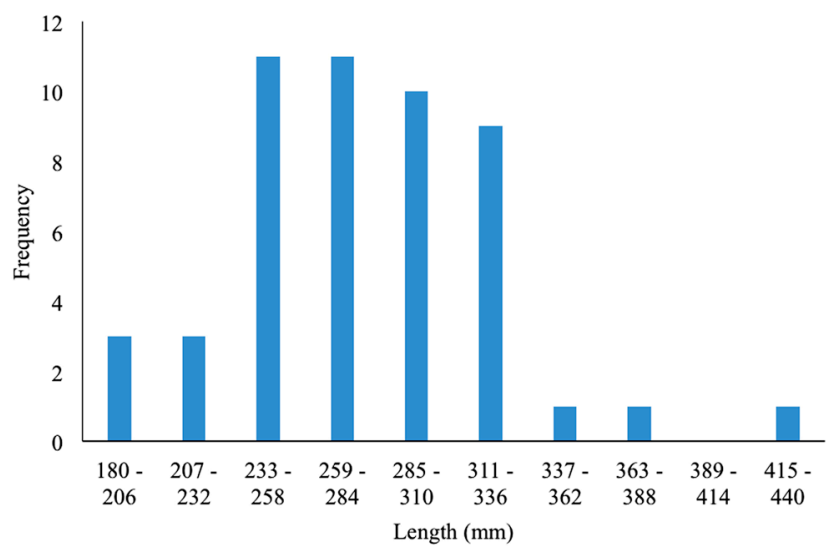

Figure A2-2. Length distribution of whitefish selected for parasite sampling.

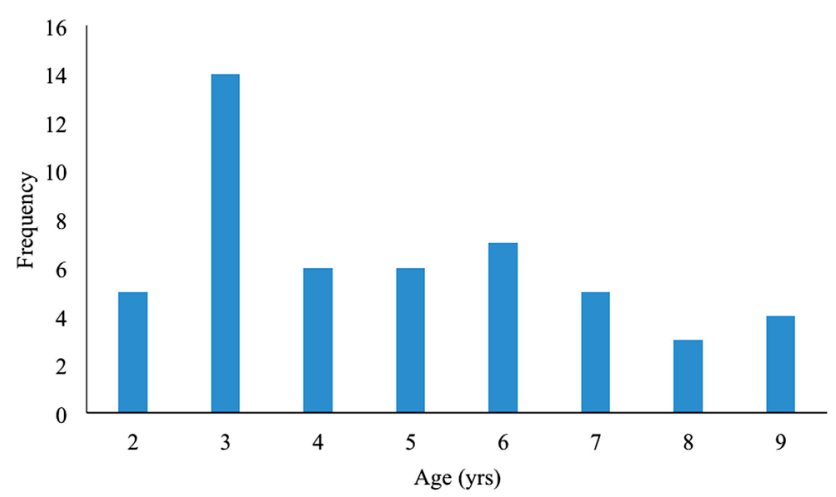

Figure A2-3. Age distribution of whitefish selected for parasite sampling.

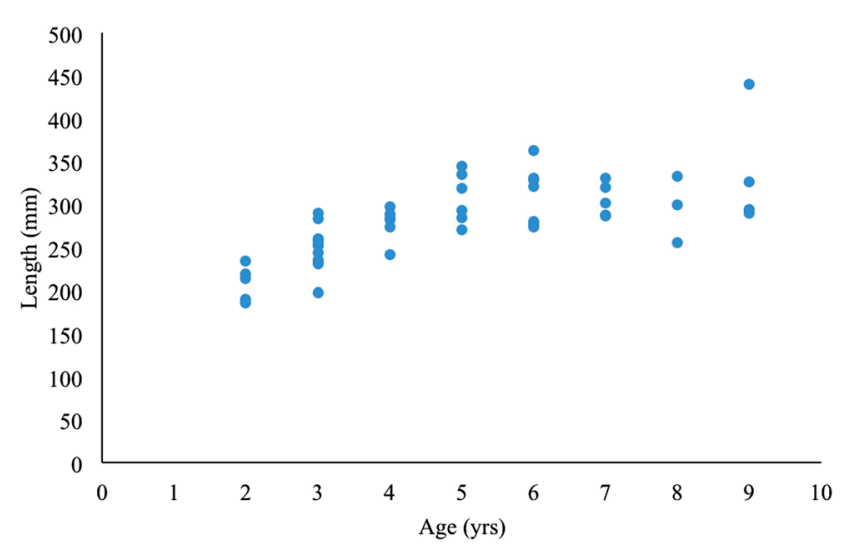

Figure A2-4. Length of whitefish selected for parasite sampling related to age.

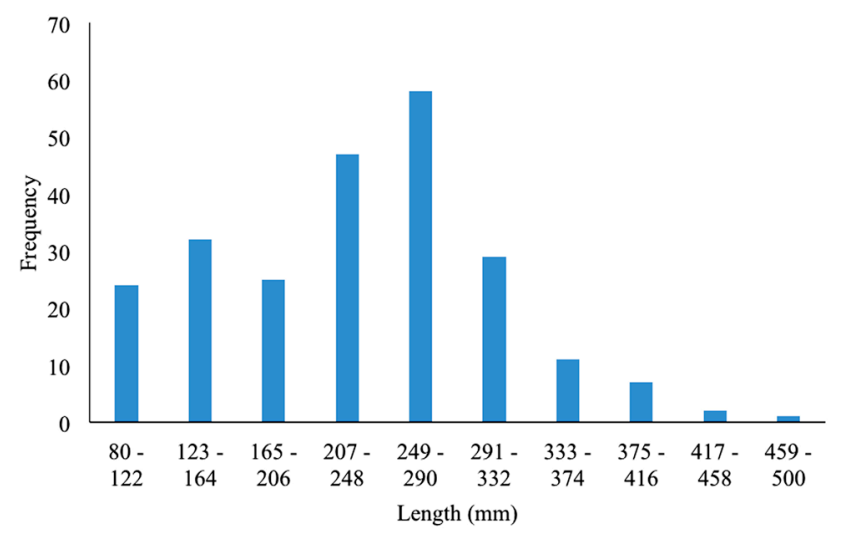

Figure A2-5. Length distribution of charr caught.

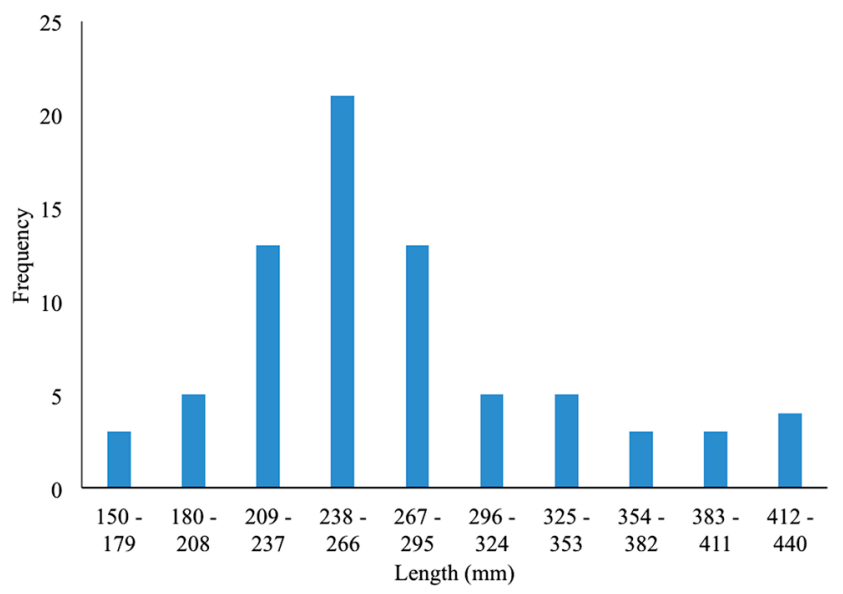

Figure A2-6. Length distribution of charr selected for parasite sampling.

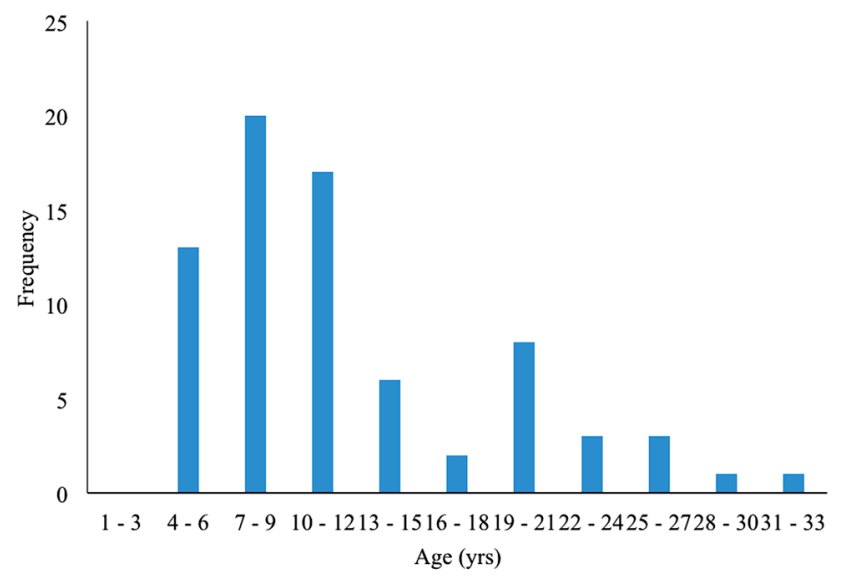

Figure A2-7. Age distribution of charr selected for parasite sampling. 
Appendix 2 continued.
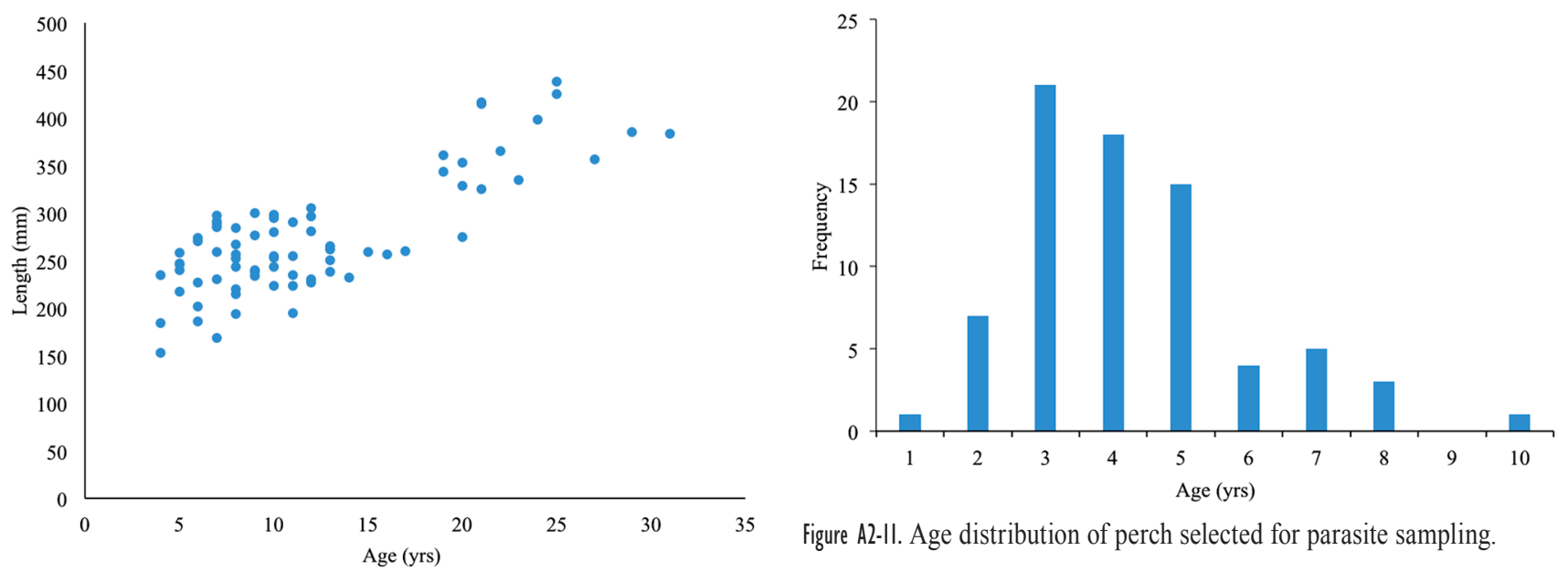

Figure A2-8. Length of Arctic charr selected for parasite analysis in relation to age.

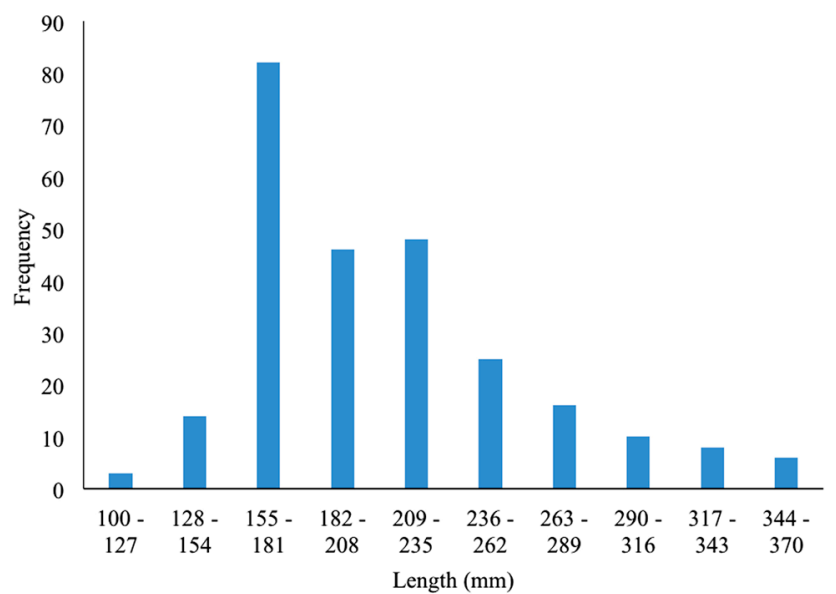

Figure A2-II. Age distribution of perch selected for parasite sampling.

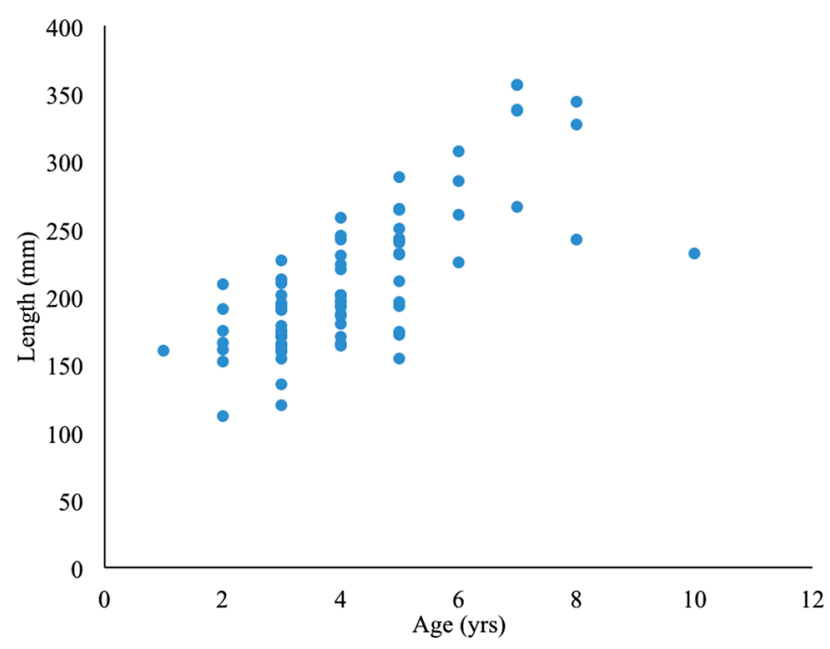

Figure A2- 9. Length distribution of perch caught

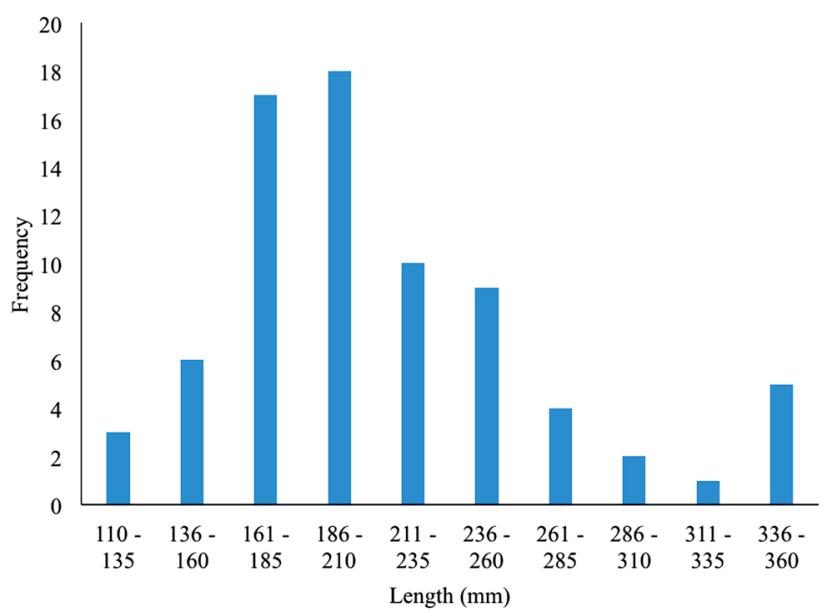

Figure A2-10. Length distribution of perch selected for parasite sampling. 